INTERNATIONAL FOOD

POLICY RESEARCH INSTITUTE

sustainable solutions for ending hunger and poverty

IFPR ${ }^{\circledR} \quad$ Supported by the CGIAR

IFPRI Discussion Paper 01161

February 2011

\title{
Economic Transformation in Ghana
}

Where Will the Path Lead?

\author{
Shashi Kolavalli \\ Elizabeth Robinson \\ Xinshen Diao \\ Vida Alpuerto \\ Renato Folledo \\ Mira Slavova \\ Guyslain Ngeleza
}

Felix Asante

Development Strategy and Governance Division 


\title{
INTERNATIONAL FOOD POLICY RESEARCH INSTITUTE
}

The International Food Policy Research Institute (IFPRI) was established in 1975. IFPRI is one of 15 agricultural research centers that receive principal funding from governments, private foundations, and international and regional organizations, most of which are members of the Consultative Group on International Agricultural Research (CGIAR).

\section{PARTNERS AND CONTRIBUTORS}

IFPRI gratefully acknowledges the generous unrestricted funding from Australia, Canada, China, Denmark, Finland, France, Germany, India, Ireland, Italy, Japan, the Netherlands, Norway, the Philippines, South Africa, Sweden, Switzerland, the United Kingdom, the United States, and the World Bank.

\section{AUTHORS}

Shashi Kolavalli, International Food Policy Research Institute

Senior Research Fellow, Development Strategy and Governance Division

Elizabeth Robinson, University of Gothenburg

Visiting Fellow, International Food Policy Research Institute

Xinshen Diao, International Food Policy Research Institute

Senior Research Fellow, Development Strategy and Governance Division

Vida Alpuerto, International Food Policy Research Institute

Research Analyst, Development Strategy and Governance Division

Renato Folledo, International Food Policy Research Institute

Research Analyst, Development Strategy and Governance Division

Mira Slavova, International Food Policy Research Institute

Postdoctoral Fellow, Development Strategy and Governance Division

Guyslain Ngeleza, International Food Policy Research Institute

Postdoctoral Fellow, Development Strategy and Governance Division

Felix Asante, University of Ghana

Senior Research Fellow, Institute of Statistical, Social and Economic Research

\begin{abstract}
Notices
${ }^{1}$ IFPRI Discussion Papers contain preliminary material and research results. They have been peer reviewed, but have not been subject to a formal external review via IFPRI's Publications Review Committee. They are circulated in order to stimulate discussion and critical comment; any opinions expressed are those of the author(s) and do not necessarily reflect the policies or opinions of IFPRI.

2.The boundaries and names shown and the designations used on the map(s) herein do not imply official endorsement or acceptance by the International Food Policy Research Institute (IFPRI) or its partners and contributors.
\end{abstract}

Copyright 2012 International Food Policy Research Institute. All rights reserved. Sections of this material may be reproduced for personal and not-for-profit use without the express written permission of but with acknowledgment to IFPRI. To reproduce the material contained herein for profit or commercial use requires express written permission. To obtain permission, contact the Communications Division at ifpri-copyright@cgiar.org. 


\section{Contents}

Abstract $\quad$ V

Acknowledgments $\quad$ vi

1. Introduction 1

2. Characterization of the Economy 2

3. Structure of Employment 13

4. Linkages 15

5. Location of Population and Economic Activities 19

6. Conclusions 27

Appendix A: Supplementary Tables $\quad 28$

Appendix B: Classification Rules to Define a Household According to the Three Agglomeration Categories $\quad 31$

$\begin{array}{ll}\text { References } & 32\end{array}$ 


\section{Tables}

2.1-Land expansion and land productivity in Ghana, 1994-2006 5

2.2-Ghanaian firm size $\quad 9$

3.1-Employment by sector (percent of total), 1965-2006 13

4.1-Input-output relationship in 2007 (value of sector's output $=1.00$ ) 15

4.2-Percentage of population classified as poor by location $\quad 18$

5.1-Percentage of households with nonagricultural income by location and type of households 22

5.2 - Share of agricultural and nonagricultural income in household total income 23

5.3- Shares of manufacturing and services in total nonagricultural income, 2005-2006 24

A.1-Population and population density by different agglomeration categories 28

A.2-Number of households classified in different locations and agglomeration categories 29

A.3-Share of population in different locations and agglomeration categories 29

A.4-Share of self-employment income by location 30

\section{Figures}

2.1-Sector share of GDP, 1965-2008 2

$2.2-$ Measure of agricultural diversification 4

2.3-Agricultural net imports excluding cocoa 6

2.4-Relative contribution of industrial subsectors to total industrial GDP, 1993-2009 (\%) 7

2.5-Contribution of industry sector and manufacturing subsector to GDP in select African countries 7

2.6-Composition of the service sectors, 1993-2009 11

5.1 -Urban agglomerations and their periphery areas 20

5.2 - Structure of wage service income (for households with wage income as a group) 25

5.3- Structure of self-employment service income (for households with self-employment income as a group) 


\begin{abstract}
In the context of the Ghanaian government's objective of structural transformation with an emphasis on manufacturing, this paper provides a case study of economic transformation in Ghana, exploring patterns of growth, sectoral transformation, and agglomeration. We document and examine why, despite impressive growth and poverty reduction figures, Ghana's economy has exhibited less transformation than might be expected for a country that has recently achieved middle-income status. Ghana's reduced share of agriculture in the economy, unlike many successfully transformed countries in Asia and Latin America, has been filled by services, while manufacturing has stagnated and even declined. Likely causes include weak transformation of the agricultural sector and therefore little development of agroprocessing, the emergence of consumption cities and consumption-driven growth, upward pressure on the exchange rate, weak production linkages, and a poor environment for private-sector-led manufacturing.
\end{abstract}

Keywords: economic transformation, agglomeration, Ghana 


\section{ACKNOWLEDGMENTS}

The authors have benefited from the conference Economic Transformation in Sub-Saharan Africa, jointly organized by IFPRI and University of Ghana on May 10-11, 2011, in Accra, Ghana. The authors particularly thank Dr. Aryeetey, discussant of the presentation based on this paper in the conference, for his valuable suggestions and comments. 


\section{INTRODUCTION}

Ghana has long been regarded as one of Sub-Saharan Africa's star performers (Coulombe and Wodon 2007). In the early 1960s Ghana had one of the richest economies in Sub-Saharan Africa (SSA). It was also one of the earlier African economic reformers, with a series of reforms beginning in 1983. These reforms included the abolition of price controls, the opening of capital markets, reductions in import tariffs, and privatization of many state-owned enterprises (Sandefur 2010). Since then Ghana has exhibited strong and sustained growth and poverty reduction (Aryeetey and McKay 2007; Sandefur 2010) and has now reached middle-income status.

Ghana in several ways can be considered a benchmark for other African countries that are seeking transformation. The role that transformation plays in the course of development is well understood by both development economists and policymakers in the developing world. Transformation is understood as a process in which labor moves from traditional activities in agriculture and other primary sectors to modern industry. It is also a process in which population moves to urban areas, creating opportunities for the development of nonagricultural activities and improved welfare, if urban blight can be managed. Ghana's Medium Term Development Policy Framework clearly states that the midterm development plan in Ghana is to "lay the foundation for the structural transformation of the economy within the decade ending 2020, through industrialization, especially manufacturing, based on modernized agriculture and sustainable exploitation of Ghana's natural resources, particularly minerals, oil and gas" (NDPC 2010, 5).

Consistent economic growth in Ghana, which has been ongoing for almost 30 years, has accelerated in the past 5 years. Ghana has also seen rapid urbanization in recent years, with up to half of the population reported to be living in urban areas in 2009 , yet with only a modest shift away from a predominantly agriculture-based economic structure. Agriculture still contributes more than one-third of gross domestic product (GDP) and employs more than 50 percent of the labor force. Progress in modern and non-resourcebased industrial development, especially in manufacturing, is slow. Thus, despite impressive growth, Ghana's economy is relatively undiversified with little change in its economic structure over the past two decades (Lejarraga 2010). Ghana's exports continue to be driven by cocoa and gold, which have accounted for almost 80 percent of total exports in recent years, primarily driven by rising world market prices (Yusof 2010). With the recent discovery of oil and natural gas, the economy is likely to be further dominated by natural resources.

In this paper, in the context of Ghana's medium-term plans and in particular the government's objective of achieving structural transformation with an emphasis on manufacturing, we explore patterns of growth, structural change, agglomeration, and their effects on household livelihoods in Ghana. We document and examine along which dimensions Ghana is and is not transforming. Our paper is guided by a number of stylized facts and hypotheses that are widely accepted by development economists in studying economic transformation. First, transformation is generally couched in terms of changes in economic structure in which there is a transition from an agricultural economy to a nonagricultural and more diversified economy. We consider the extent to which Ghana's economy has followed this pattern. Second, economic transformation typically follows a path of agricultural productivity growth that releases resources from agriculture into other, more dynamic economic sectors, typically manufacturing. We analyze the performance of agriculture in Ghana and pay particular attention to productivity change in this sector. Third, urbanization is generally believed to result in agglomeration benefits that enable accelerated growth through economies of scale and clustering of economic activity. We pay particular attention to the patterns of urbanization and nonagricultural sources of income for households at different locations and consider to what extent Ghana's economy has benefited from economies of scale associated with urbanization and agglomeration.

We organize the rest of the paper in the following way: In Section 2 we focus on transformation of output, characterizing the evolution, structure, and performance of Ghana's economy at the sector level. We examine the structure of employment in Section 3, and sectoral and spatial linkages and welfare indicators in Section 4. In Section 5, we explore and assess the spatial pattern of agglomeration of population in the country and its association with economic activities. Finally, we provide some conclusions in Section 6. 


\section{CHARACTERIZATION OF THE ECONOMY}

\section{Ghana's Growth Record}

Since the mid-1980s Ghana's economic performance has been characterized by steady and sustained growth. Between 1985 and 2010, the annual GDP per capita grew every single year. In only three of those years was the GDP per capita growth rate below 1 percent, and in most years per capita GDP grew at 2-3 percent and total GDP at 4-5 percent annually. Growth started to accelerate after 2004, and the annual GDP growth rate was greater than 6 percent between 2005 and 2010. The recent national account rebasing has adjusted Ghana's growth figures upward after 2006, with the growth rate in 2008 and 2009 more than 7 percent per year. The revised GDP in 2009 gives Ghanaians the highest per capita income in West Africa and makes Ghana a low-middle-income country with per capita GDP of more than US $\$ 1,000$. Ghana's impressive growth performance not only contrasts with its experience before the mid1980s but is also unusual globally (Breisinger and Diao 2008). Among all developed and developing countries, only a few have achieved consistent growth over such a long period. While growing steadily, Ghana has also dramatically reduced the incidence of poverty from 51.7 percent in 1991/92 (GSS 2007) to 28.5 percent in 2005/06 (Ghana Living Standard Survey, GLSS5), suggesting a broad-based growth. If Ghana continues along this trajectory, it is likely to achieve the Millennium Development Goal (MDG) 1 of halving its 1990s' poverty rate before the target year of 2015, thereby outperforming many other African countries in this respect.

\section{Evolution of Sectoral Composition in Ghana's Economy}

Ghana's sectoral structure after independence was typical of many postcolonial countries. A small proportion of the population was involved in the higher-productivity formal sector, with the majority of the population in low-productivity agricultural or informal nonagricultural activities (Andrae 1981). Agriculture dominated the economy in terms of contributions to GDP and employment. Exports were typically primary agricultural or mining products, and most nonagricultural consumer goods were imported (Andrae 1981). While agriculture typically contributed between 40 and 50 percent of GDP in the early postcolonial period, it rose in importance in the late 1970s and early 1980s, reflecting the decline of Ghana's industry sector during this period (Figure 2.1).

Figure 2.1-Sector share of GDP, 1965-2008

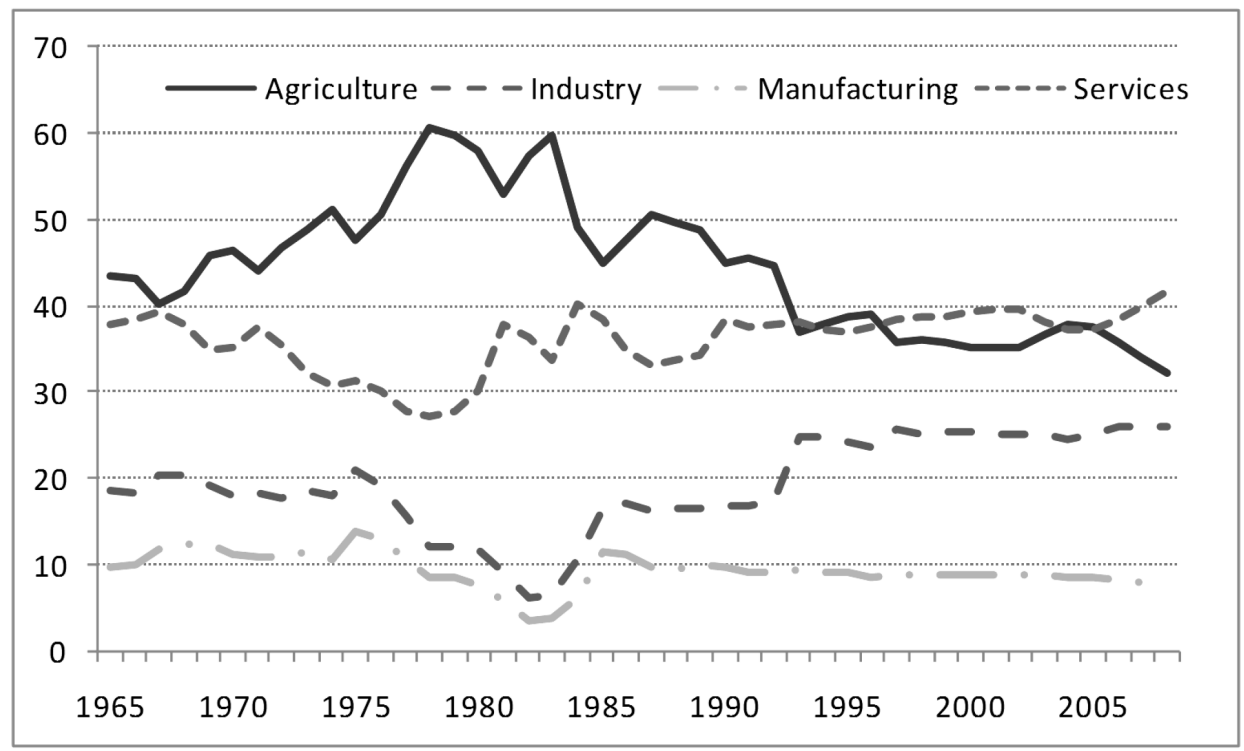

Source: World Bank 2009d. 
Ghana undertook one of Africa's most ambitious structural adjustment programs in the late 1980s that included the removal of subsidies and price controls, state enterprise divestiture, improved publicsector management, and banking reform (Sandefur 2010). During the sustained growth that followed, the contribution of the industry sector recovered from a low of 7 percent, but its contribution to GDP did not exceed 26 percent (see Figure 2.1). The recent rebasing further adjusts the share downward, from 20.8 percent in 2006 to 18.6 percent in 2010 . With recovery in the nonagricultural sectors after 1983, the contribution of agriculture to GDP has gradually declined. However, the decline is modest, and agriculture continues to be an important sector in Ghana's economy, contributing more than one-third of GDP. The recent rebasing adjusts the agricultural share of GDP downward only slightly, to about 30 percent between 2006 and 2009. The contribution of the service sector to GDP was relatively stable in the entire postcolonial period, but its importance in the economy has been increasing in recent years. The rebasing makes the service sector the largest economic sector in Ghana, accounting for 50 percent of GDP in recent years. In short, since the mid-1980s, consistent growth across sectors suggests that structural change, as measured by sectoral composition, has been modest; but rebased national accounts suggest that structural change may have been more than modest in recent years, with an expanding service sector and a diminishing agricultural sector.

\section{Agriculture}

Agriculture is transforming slowly, led primarily by development of nontraditional exports. However, productivity has changed only marginally in traditional agriculture. Because of this, Ghana is losing competitiveness in the domestic market for many agricultural products that the country has traditionally produced.

Agriculture has been the backbone of Ghana's economy throughout the postindependence period until recent years, when the service sector began to dominate the economy. Agriculture is dominated by crop production in Ghana, with crops other than cocoa accounting for nearly two-thirds of the agricultural GDP. Although cocoa is the most important export crop, it accounts for only 10-15 percent of agricultural GDP, less than even root crops alone. However, agricultural exports, comprising cocoa, oil palm, cotton, rubber, and fruits, account for around 20 percent of agricultural GDP.

Agriculture can play an important role in a country's transformation to a modern economy if the expansion of nontraditional agriculture and modernization of traditional agriculture provide significant sources of productivity gains. In such a case, diversification into production of higher-unit-value products, often with the potential for exports, is an indication of both agricultural and economic transformation. Through the expansion of nontraditional agriculture, agriculture can become more productive and more integrated with the nonagricultural economy as well. Indeed, experiences of successfully transformed developing countries show that rapid diversification of agricultural exports has accelerated growth in agriculture and general economic transformation (Breisinger and Diao 2008; Breisinger, Diao, Benin et al. 2010; Breisinger, Diao, and Thurlow. 2011).

To assess whether there has been such transformation in Ghana, we construct the Herfindahl index for agricultural exports (including agroprocessing products) to measure export diversification. A higher value of the normalized Herfindahl index, which ranges from 0 through 100, indicates a more concentrated agricultural export structure. So, for example, if cocoa were the only agricultural export product in Ghana, the index value would be 100. We find that between 1965 and 2008, the normalized Herfindahl index for Ghana fell from 50-60 before the mid-1980s to 28-38 in recent years, suggesting that export diversification has occurred. Growth of agricultural exports of both cocoa and noncocoa products has accelerated in the recent years. Annual average growth in total agricultural exports was more than 9 percent between 1993 and 2000, and it increased to 13.4 percent between 2000 and 2008. Between 2000 and 2008, noncocoa agricultural exports grew at 9.6 percent annually. However, the speed of diversification has slowed down after the mid-1990s, and indeed a reverse trend is seen in the recent years because of the surge in cocoa exports. We illustrate this by presenting the share of cocoa-the most important export crop - in total agricultural exports, the annual growth rate of cocoa and noncocoa exports, and Ghana's Herfindahl index for exports in Figure 2.2. We find that the trend of the Herfindahl 
index matches closely the trend of the share of cocoa in agricultural exports, suggesting that the primary reason for the reverse trend in the index is due to increased cocoa exports driven by increased production and high world market prices. The correlation between the 5-year average cocoa export growth rate and Herfindahl index is as high as 0.64 in the 15 years from1994 through 2008, indicating that the higher the cocoa exports, the lower the export diversification in this period. Although Ghana's agriculture is transforming through diversification into nontraditional products, the role of cocoa in Ghana's agricultural exports has not diminished.

Figure 2.2-Measure of agricultural diversification

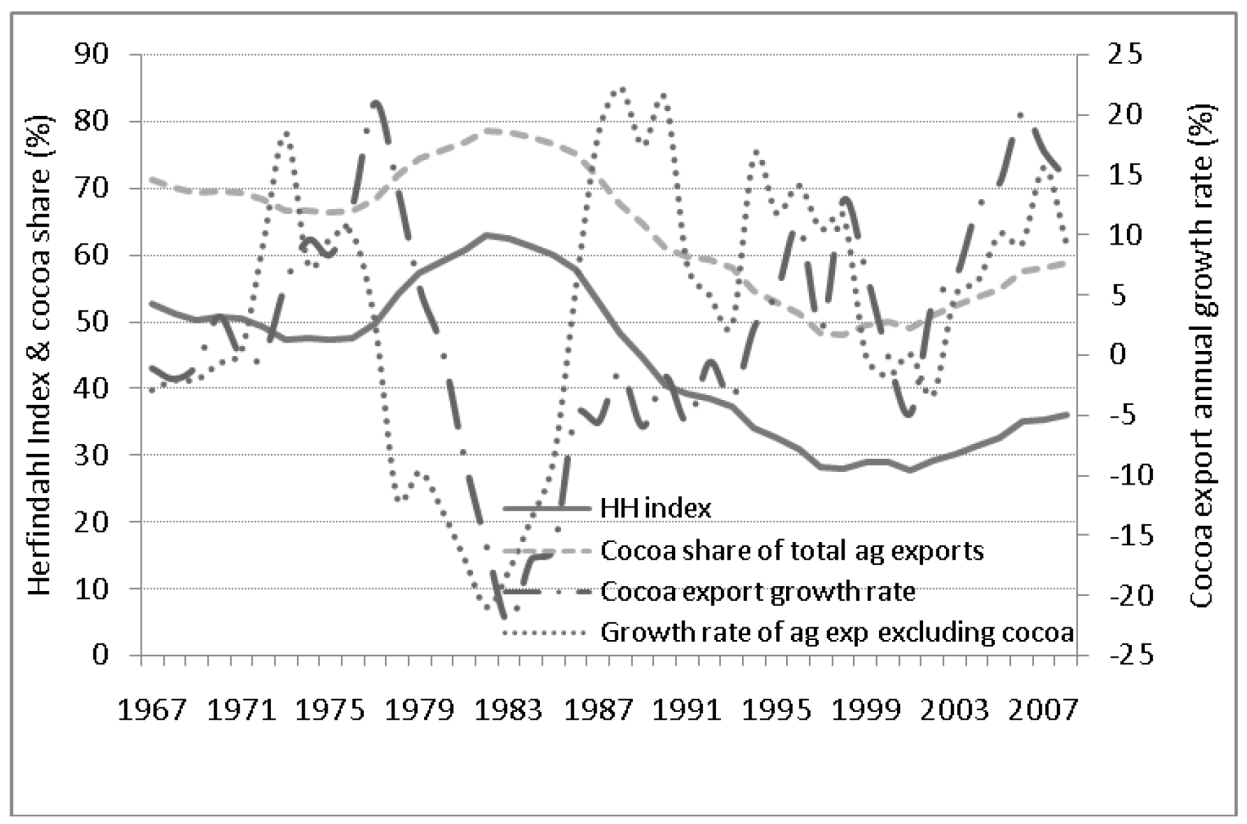

Source: Authors' calculations using United Nations Comtrade data 2010.

Notes: HH, Herfindahl-Hirschman; ag, agriculture; exp, exports.

Modernizing traditional agriculture such as staple crop and livestock production is another important source of agricultural transformation that can lead to increased land productivity and greater competitiveness. However, though the agricultural sector in Ghana has grown at 5 percent per year during the past decade, much of this growth has been driven by an expansion of land area (primarily for cocoa; see Table 2.1) rather than improved yields, and the contribution from productivity increase is rather modest (World Bank 2007, Vol. 2; Steedman 2003; Bogetic et al. 2007; Breisinger et al. 2008; Breisinger, Diao, Kolavalli et al. 2011). Yields of major food crops in Ghana have improved only modestly during the last 12 years and, according to the Ministry of Food and Agriculture, are typically 20-60 percent below their achievable level with available technologies, which include the use of modern inputs such as fertilizers and improved seeds. 
Table 2.1—Land expansion and land productivity in Ghana, 1994-2006

\begin{tabular}{|c|c|c|c|c|c|c|}
\hline & \multirow[b]{2}{*}{1994} & \multirow[b]{2}{*}{2000} & \multirow[b]{2}{*}{2006} & \multicolumn{3}{|c|}{ Annual growth rate } \\
\hline & & & & 1994-2006 & 1994-1999 & 2000-2006 \\
\hline \multicolumn{7}{|c|}{ Land productivity (cedi per hectare) ${ }^{*}$} \\
\hline Crops and cocoa & 155 & 112 & 159 & 0.91 & -4.77 & 5.97 \\
\hline Cocoa & 162 & 87 & 188 & 1.56 & -10.49 & 13.67 \\
\hline Crops other than cocoa & 154 & 121 & 149 & 0.69 & -4.97 & 3.62 \\
\hline \multicolumn{7}{|c|}{ Land allocation (in 1,000 hectares) } \\
\hline Cultivated land & 4,500 & 6,100 & 7,195 & 4.10 & 5.39 & 2.79 \\
\hline Cocoa land & 687 & 1,500 & 1,835 & 7.01 & 13.62 & 3.42 \\
\hline Crops other than cocoa & 3,813 & 4,600 & 5,360 & 3.31 & 3.59 & 2.58 \\
\hline
\end{tabular}

Sources: Calculated using data from Food and Agriculture Organization 2008, International Monetary Fund (various issues of Ghana statistics), and Ghana Statistical Services.

Note: $\quad$ *Land productivity is calculated as GDP at constant 2000 prices divided by hectares of cultivated land. The value is reported in new Ghana cedi.

Land productivity, measured by total crop GDP in constant terms, has barely changed in the last 12 years. Total land productivity decreased between 1994 and 1999 both in cocoa and non-cocoa crops, and recovered only in recent years, primarily driven by growth in cocoa (Table 2.1). Indeed, only in the cocoa sector has land productivity grown modestly at 1.6 percent per year between 1994 and 2006 . Following market reforms that passed on an increased share of export prices to farmers and government investments in the provision of public goods, complemented by favorable world prices in recent years, cocoa production has increased considerably (excluding the period 1996-2000; Kolavalli and Vigneri 2011). The contribution of cocoa to agricultural growth is almost three times its share in the sector.

A consequence of the inability to increase productivity is that Ghana's agricultural sector is not able to compete with the imports of products that are traditionally produced in the country; and excluding cocoa, Ghana has recently become a net agricultural importer of primary foods and agroprocessing products. The value of net agricultural imports reached almost $\$ 1$ billion in 2008 (Figure 2.3), such that almost one-third of foreign exchange earned by exporting cocoa is used to pay for imported foods and other agricultural products. The increasing demand for meat, rice, and processed foods, which is a result of growing urbanization and a growing middle class, is increasingly met by imports. For example, rice and chicken imports have surged after Ghana liberalized its domestic market by lowering its import barriers in the early 1990s. Ghana currently imports around 60 percent of rice and 90 percent of poultry meat consumed domestically, the demand for which is highly income elastic, suggesting continued increases in imports in the absence of competitive production in the country. Ghana has also seen a surge in the import of many agroprocessing products such as canned tomatoes and tomato paste, the consumption of which is substituting for the consumption of locally grown fresh tomatoes (Robinson and Kolavalli 2010). 
Figure 2.3-Agricultural net imports excluding cocoa

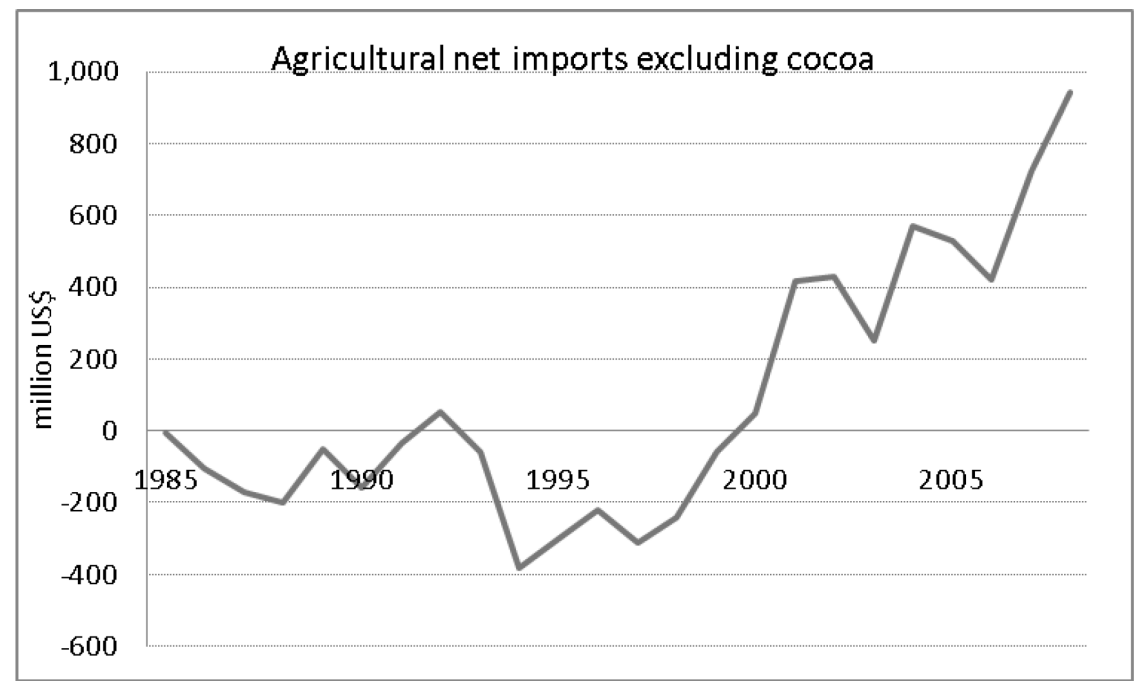

Source: Authors' calculations using United Nations Comtrade data 2010.

Agricultural transformation takes place through the adoption of modern technologies and modern inputs to produce for competitive domestic and international markets. The available evidence shows that Ghana's agriculture is characterized by low inputs, high dependence on rainfall, and production on predominantly smallholder farms (Asmah 2011). Only 19 percent and 7 percent of households in GLSS5 reported use of inorganic fertilizer and renting equipment, respectively (Quinones and Diao 2011). Inadequate innovation in small-scale agriculture and poor transport and distribution channels have all been identified as contributors to slow agricultural productivity growth (Aryeetey 2005; Lay and Schuler 2007).

Transforming traditional agriculture requires institutional change in Ghana's traditional land tenure system. Traditional land access arrangements are seen to be one factor that has deterred investments in productivity-enhancing commercial agriculture. Ghana has more than 100 statutes on land ownership, tenure, and planning and use, in addition to different customary laws as they pertain to specific localities (Larbi 2006). Such complex land tenure systems, combined with awkward and inconsistent procedural arrangements for deed and title registration, appear to limit the ability of investors to acquire large tracts of land. Some estimates suggest that if farmers had security of land tenure, agriculture could contribute an additional 2 percent to GDP growth (Nankani nd.).

\section{Industry}

Historically, rapid economic growth has been associated first and foremost with the expansion of industrial activities (Rodrik 2006). Measured by growth and structural change within industry, Ghana's industry is the least transformed sector in the economy, with the relative contributions of the industrial subsectors little changed between 1993 and 2005. For the past 15 years and more, the share of industry in Ghana's overall GDP has remained virtually constant at around 25 percent (and less than 20 percent using rebased data). The contribution of mining and of electricity and water has remained fairly constant at around 21 percent and 10 percent of industry GDP, respectively. Although in most countries, manufacturing growth has led structural transformation, in Ghana the share of manufacturing in its industrial GDP has declined from more than 36 percent to less than 30 percent. The most dynamic and largest subsector in Ghana's industrial sector is construction, which is generally nontraded and has much weaker linkages with the rest of the economy than manufacturing. Construction growth has been driven primarily by an urban housing boom and infrastructure developments (Figure 2.4). 
Figure 2.4-Relative contribution of industrial subsectors to total industrial GDP, 1993-2009 (\%)

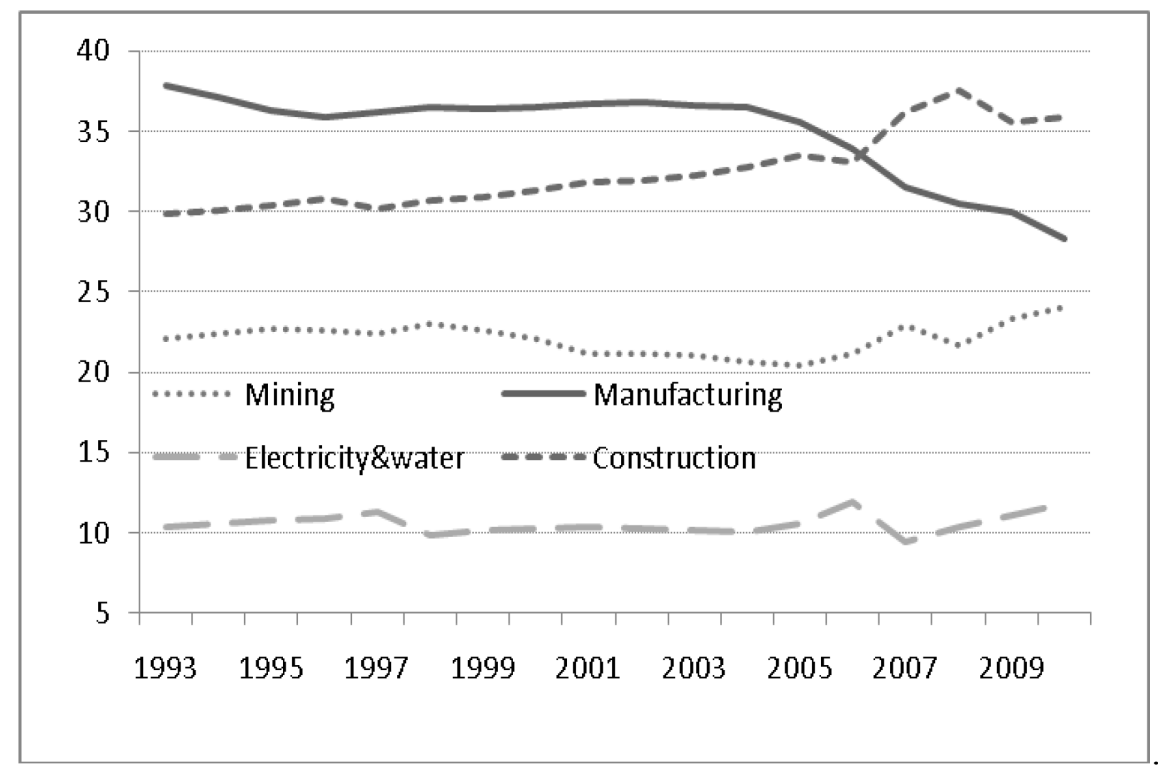

Source: Authors' calculations from GSS 2011b.

\section{Manufacturing}

Using rebased data, the share of Ghana's manufacturing subsector is small, even compared with many other African countries (Figure 2.5). We can see from Figure 2.5 that only two countries in the sample, Tanzania and Ethiopia, have both a smaller share of manufacturing in GDP and a smaller share of total industry in GDP.

Figure 2.5-Contribution of industry sector and manufacturing subsector to GDP in select African countries

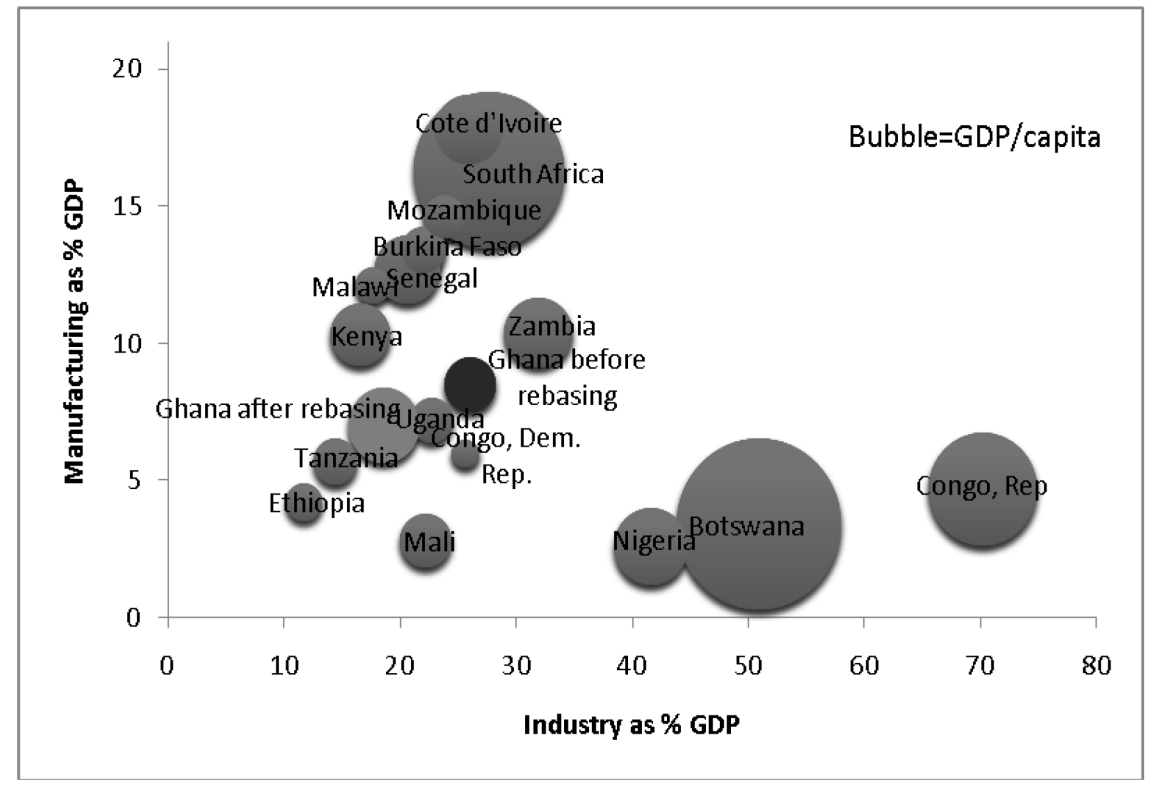

Source: World Development Indicators 2009. 
Manufacturing in Ghana is dominated by agriculture-related activities, including food and wood processing and textiles, which accounted for more than 60 percent of manufacturing GDP in 2007 (Breisinger, Diao, Kolavalli et al. 2011). The average annual growth rate in manufacturing has been only 3.2 percent between 1994 and 2010, the lowest among Ghana's industry subsectors. Many factors have contributed to the poor performance of Ghana's manufacturing subsector, including high labor costs, high costs of electricity and raw materials, and both imported and domestically produced obsolete machinery (Yusof 2010).

During the 1960s manufacturing grew at relatively high rates, benefiting from a state-led development strategy that included import substitution. A number of large industrial enterprises, including Volta Aluminum Company (Valco) smelter, sawmills, and timber processing plants; cocoa processing plants; breweries; cement manufacturing; oil refining; textile manufacturing operations; and vehicle assembly plants were created in that period. This period of growth was followed by more than a decade of deindustrialization, and most of these enterprises did not survive in this era of restrictive trade regimes, which led to scarcity of the foreign exchange that was needed to import necessary intermediates and to poorly designed industrialization policies and high protection barriers (Steel 1972; Dinye and Nyaba 2001; Ackah and Kutsoati 2008). Ghana's efforts to develop its aluminum industry through the Volta Aluminium company (Valco), for example, failed due to a combination of factors, including the discovery of large bauxite reserves in Australia and Brazil that made it more economical to import semiprocessed alumina rather than to rely on local supplies (Encyclopedia of the Nations n.d.).

Attracting foreign direct investment (FDI) is an important aspect of accelerating growth in lowincome countries (Marr 1997). During Ghana's prereform years in the 1960s, 1970s, and early 1980s, the government made little commitment to promote private investments, and FDI into Ghana was relatively low. Instead it undertook a state-led industrialization program. However, between 1986 and 1995, FDI flows increased dramatically from around \$5 million per year in 1986 to \$245 million in 1995, mainly driven by the privatization of the Ashanti Goldfields Corporation. Indeed, Ghana was one of the top three Sub-Saharan African low-income countries that received FDI during the 1990s, attracting investors in part by the availability of natural resources (Marr 1997). By 2006 FDI in Ghana accounted for almost $\$ 450$ million.

Most FDI in Ghana has gone into mining (around 70 percent over the past 15 years), resourcebased manufacturing, and telecommunications and banking, suggesting that most FDI is resource and market seeking rather than efficiency seeking (Barthel, Busse, and Osei 2008). FDI in mining provides few jobs, because mining is a relatively capital-intensive activity that provides foreign exchange primarily through increased exports and government revenue. Moreover, few technology spillovers result from mining FDI, in contrast to efficiency-seeking FDI in manufacturing and assembly, which typically have more technology spillovers (Barthel, Busse, and Osei 2008). By 1990, 621 projects had been approved, of which 444 were in the manufacturing sector, mostly in timber and chemicals. Few were actually launched by 1990, and 80 percent of those that were launched were in the wood industry (Encyclopedia of the Nations n.d.). Access to land, property registration, and labor market problems (regulations, availability of skilled labor, and labor productivity) are key constraints to efficiency-seeking FDI in Ghana.

A number of fundamental realities affect manufacturing in Ghana, in common with many other Sub-Saharan African countries. First, most of Ghana's manufacturing firms are small and informal (Table 2.2). In parallel with the far-reaching structural adjustment program introduced in Ghana that abolished price controls, opened capital markets, and cut tariffs, the size of the informal sector has rapidly increased and the average size of industrial firms has gradually decreased (Sandefur 2010). ${ }^{1}$

\footnotetext{
${ }^{1}$ Similarly, Côte d'Ivoire, Uganda, Kenya, and Tanzania have also seen, in parallel with market-oriented reforms, an increase in the proportion of the nonagricultural labor force working in the small-scale or informal sector (Kingdon, Sandefur, and Teal 2006).
} 
Table 2.2-Ghanaian firm size

\begin{tabular}{|c|c|c|c|c|}
\hline \multirow{2}{*}{ Share } & \multicolumn{2}{|c|}{ Number of Firms } & \multicolumn{2}{|c|}{ Employment } \\
\hline & 1987 & 2003 & 1987 & 2003 \\
\hline Small $(<11)$ & $75 \%$ & $85 \%$ & $18 \%$ & $35 \%$ \\
\hline Medium (11-99) & $22 \%$ & $14 \%$ & $28 \%$ & $31 \%$ \\
\hline Large (>99) & $3 \%$ & $1 \%$ & $54 \%$ & $34 \%$ \\
\hline Total & $100 \%(8,349)$ & $100 \%(26,088)$ & $\begin{array}{c}100 \% \\
(157,084)\end{array}$ & $\begin{array}{c}100 \% \\
(243,516)\end{array}$ \\
\hline
\end{tabular}

Source: Nsowah-Nuamah, Teal, and Awoonor-Williams 2010.

Recent and detailed research undertaken by Sandefur (2010) addresses a question posed by the World Bank in the early 1990s (World Bank 1994): Was the activity of small firms in Ghana an indicator of dynamic new enterprises that would provide employment growth, or a sign of distress?

Microenterprises were found to have accounted for most of gross and net job creation between 1987 and 2003, but these firms have not grown into medium- or large-scale enterprises over time. In Ghana small enterprises have been found to die early and die small. Large firms in Ghana are born big.

Ghana's labor policies appear to constrain the ability of small firms to expand. In particular, compared with other countries, Ghana is an outlier with regard to redundancy costs. Ghanaian firms pay an average of 178 weeks of salary when making a worker redundant (Lejarraga 2010). Ghana's formal employment sector is characterized by high rates of unionization, resulting in wage rigidity. Estimates suggest that more than two-thirds of formal-sector jobs are subject to collective bargaining agreements (World Bank n.d.). Ghana's union wage premium is 49 percent higher than that in most African countries, including, for example, South Africa (Kingdon, Sandefur, and Teal 2006).

Homegrown manufacturing has the potential to play an increasingly important role in Ghana's transformation (Agyeman-Duah 2008), yet Ghanaians have not taken advantage of a number of existing local opportunities and traditions. For example, entrepreneurs from Vietnam and China have used modern production methods to produce traditional Ghanaian handicrafts for exports. Vietnamese firms have successfully produced and marketed Bolga baskets, and Chinese firms have revolutionized the market for kente cloth by imprinting at costs lower than traditional weaving. The automobile parts sector in the Suame Magazine area of Ghana represents another example of homegrown manufacturing that has yet to play an important role in Ghana's transformation (Agyeman-Duah 2008).

In addition to being small and weak, Ghana's manufacturing sector has failed to reach international markets. This situation is by no means unique to Ghana. Only one Sub-Saharan African country, Mauritius, has been able to successfully export labor-intensive manufactured products (Teal 1999). In almost all the countries outside Africa that have achieved middle-income status, the export structure has changed considerably during transformation, with a decline in the share of agricultural exports and an increase in the share of manufacturing (Breisinger et al. 2007). Collier and Venables (forthcoming) suggest that coastal economies have the greatest potential to develop clusters of exportoriented manufacturing companies, but Ghana has failed to benefit from its location.

Investment in product discovery determines the types of goods a country produces and exports, which in turn shape the pace of its structural change (Haussman, Hwang, and Rodrik 2006). Successfully transformed countries outside Africa, such as China and Malaysia, have benefited from policy changes that have rapidly improved the proximity of their product baskets to more sophisticated goods in the clusters produced by advanced economies. In contrast, Ghana's share of new products in the world total products was almost identical between 1962 and 2000. A troubling possibility is that Ghana's relatively abundant natural resources may inhibit a transformation of the type experienced by China and Malaysia for reasons discussed in the natural resource curse literature (Sachs and Warner 1995 and 2001).

Some macroeconomic factors constrain Ghana's development of a competitive domestic manufacturing sector. For example, the foreign exchange rate has for a long time been under tremendous upward pressure due to increased exports of natural-resource-based primary products (cocoa, gold, and soon oil will maintain the pressure), remittances from overseas migrants, and foreign aid. Empirical 
studies suggest that an overvalued exchanged rate — by pushing up prices for nontradables such as construction, services, costs of labor, and other inputs - is associated with difficulties in developing manufacturing (Rodrik 2008). Harberger (2010) suggests that with the increase in demand for nontradables, the country may be already experiencing so-called Dutch disease.

A recent World Bank (2009a) report points out several structural factors that further explain the lack of competitiveness of Ghana's economy in both export and domestic markets. These factors include rigid urban land tenure, difficulty in access to finance, and regulation in formal labor markets, which have become high barriers to entry into formal sectors, particularly for urban small and medium enterprises to start business. Besides, the likely existence of speculative bubbles in real estate primarily fueled with remittances and other inflows can seriously distort private investment toward nonproductive sectors and further can negatively affect productivity and competiveness in productive sectors.

\section{Services}

While modern services such as information and communication technologies (ICT), finance, and other business-oriented services have become increasingly important in transformation, the role that services can potentially play in transformation is rarely discussed in the "older" development literature. However, perhaps due to India's experience in developing export-oriented services, modern services are increasingly seen as a sector that can grow rapidly and be a leading force in a country's transformation. Recent studies show that the mix of skilled and unskilled labor absorbed by modern services and manufacturing is more or less similar (Eichengreen and Gupta 2011).

Ghana has a large and growing service sector that encompasses many parts of the public sector, and a wide range of private activities (construction, finance, trade) that serve demands mainly coming from or arising out of resource-based extractive industries (such as gold), remittances, and international partners' development assistance. The service sector became the largest sector in Ghana's economy in recent years, and the recent rebasing shows that the share of services in GDP reached 50 percent in 2006. Between 1994 and 2010, the service sector grew most rapidly in GDP, with an annual growth rate of 5.9 percent as compared with 5.0 percent and 4.4 percent for industry and agriculture, respectively (nonrebased figures, GSS 2011a). Indeed, service is a rapidly growing sector for Africa as a whole, at 2.2 percent per year between 1980 and 1999, compared with overall GDP growth of 2 percent (Yumkella et al. 1999). However, the most rapidly growing subsectors of services in Ghana are nontraded and are consumption related. Moreover, more than one-third of the sector relates to public and governmentrelated services such as administration, health, and education. Up until the mid-1990s the wholesale, retail, restaurants, and hotels subsectors were the major contributors to the service sector's GDP growth, after which government services became the largest services subsector. Ghana's recent growth has increasingly concentrated in the nontradable part of the economy, including nontradable industrial sectors such as energy and construction, a warning symptom of the Dutch disease and real exchange appreciation (World Bank 2009a).

India's experience of service-led transformation has been driven by rapid growth in exportoriented services. In contrast, Ghana's service sector is dominated by public services and domesticoriented private services. Only a small proportion of the service sector is export related, but even here it is still consumption related, such as with luxury hotels and restaurants that provide services to foreigners (Figure 2.6). 
Figure 2.6-Composition of the service sectors, 1993-2009

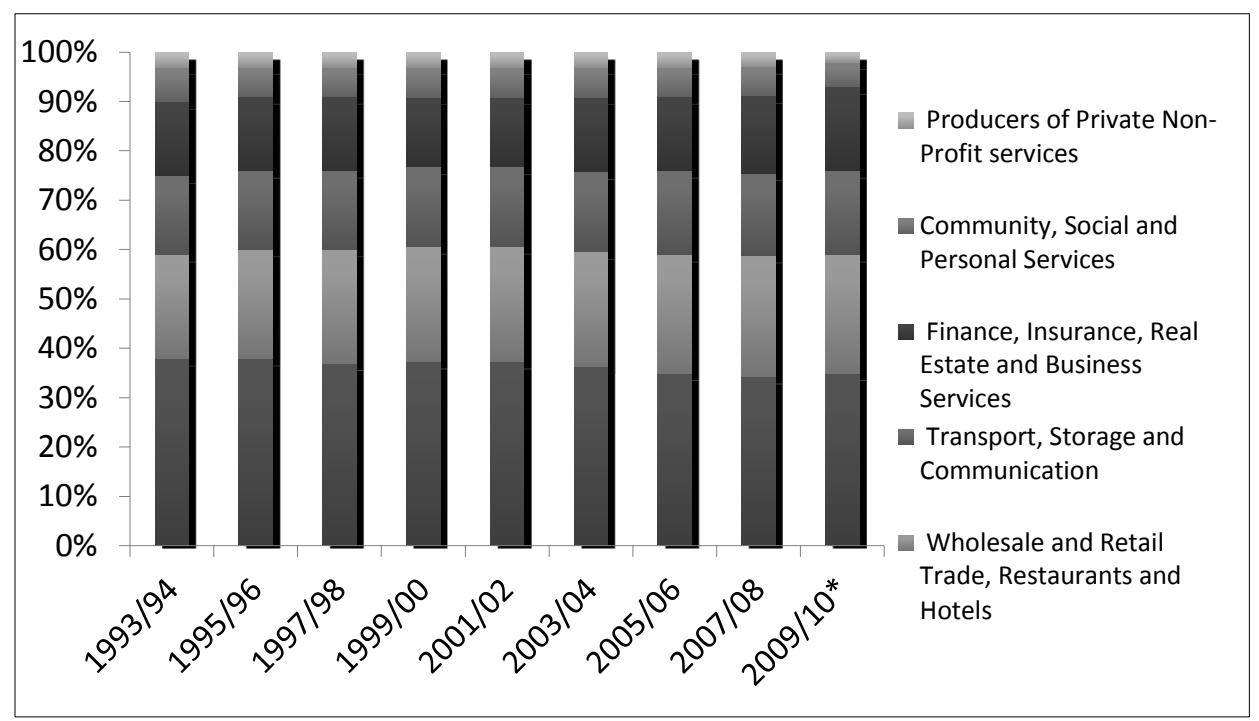

Source: Authors' calculations from GSS 2011b.

Following the economic downturn in the mid-1970s and early 1980s, the Economic Recovery Program (ERP) and the Structural Adjustment Program (SAP) in the early 1980s appear to have encouraged more growth services relative to other sectors. ${ }^{2}$ Many of the policies and programs coming out of Ghana's SAP were aimed at rehabilitation and expansion of the service subsectors, such as the Financial Sector Structural Adjustment Program (FINSAP) and the New Educational Reform Program (NERP) under the ERP and SAP.

\section{The Size and Role of the Government in the Service Sector}

In the late 1970s, Ghana's public sector accounted for three-quarters of formal wage employment. It was characterized by low wages, low skills, a low ratio of nonwage-to-wage expenditures, and competition between ethnic groups for resources (Collier and Gunning 1999). As in many African countries, the result was high public expenditure but poor public services. Ghana's government has been heavily involved in many service activities, the real estate subsector in particular since the late 1950s. As part of the 10-year development plan following independence, the State Housing Corporation (SHC) and the Tema Development Corporation (TDC) were established to provide residential houses for the entire nation and the Tema industrial hub, respectively. Only in the late 1980s did the government withdraw from direct involvement in house production and financing, leading the way for private-sector growth in this subsector. The government does, however, continue to be involved in the provision of affordable housing in the main cities. The government was also heavily involved in the communication subsector until 1994, when the 5-year Accelerated Development Policy (ADP) was introduced and the market was opened to private-sector participation.

Government services have for many decades been the major contributor to the service sector's GDP growth (Ghana's civil service is the country's largest single employer), although growth in the subsector has declined since 2009 in part due to the government's restrictive macroeconomic policy.

Ghana performs well in infrastructure including power, the transport network, and ICT connectivity. Compared with many other countries in SSA, Ghana is in a better situation with regard to household access to electricity, paved roads, and road density. On the other hand, the country has lower access to fixed and mobile telephones, Internet, and personal computers. In common with many African

\footnotetext{
${ }^{2}$ According to the State of the Ghanaian Economy by ISSER (1993).
} 
countries, the general consensus is that improved infrastructure is essential for accelerated growth in Ghana (World Bank 2007, Vol. 2).

ICTs have a demonstrable and positive impact on income growth in industrialized countries (Röller and Waverman 2001). For less-developed countries, the ICT sector carries the promise of leapfrogging stages of industrialization and entering directly into the knowledge economy of the 21 st century. In Ghana, fixed broadband connectivity is the major bottleneck in terms of affordability.

However, with the landing of four ${ }^{3}$ international connectivity undersea cables due to be operational in Accra by the close of 2011, affordability of international bandwidth is poised to improve.

\footnotetext{
${ }^{3}$ SAT-3 (120 gigabytes), Glo One (640 gigabytes), Main One (640 gigabytes), and West Africa Cable System (WACS)
} $(5,120$ gigabytes $)$. 


\section{STRUCTURE OF EMPLOYMENT}

In many countries that have experienced relatively rapid economic growth, labor has been released from agriculture and moved into other economic activities through increased agricultural productivity. Though in many sub-Saharan African countries the agricultural labor exit rates tend to be rapid, this may not be due to any change in agricultural productivity (Headey, Bezemer, and Hazell 2010). Compared with other countries in SSA, Ghana sits somewhat in the middle in this trend, in a group that includes Sierra Leone and Rwanda, with moderate exit rates (though high relative to those found in Asia) of between 10 and 20 percent. Those countries with exit rates lower than 10 percent, such as Ethiopia, remain more dependent on agriculture.

Despite relatively rapid agricultural labor exit rates, Ghana's employment is still dominated by the agricultural and rural sectors (World Bank nd). It is true that most employment data in Sub-Saharan African countries are questionable, given that agricultural production is often not a full-time job and small-scale self-employment in nonagricultural activities is unlikely to be covered by employment statistics. Nevertheless, a gradual but steady decline in agricultural employment is apparent, as well as a corresponding increase in employment in services from 22 percent in the 1960 s to just over 30 percent between 2000 and 2006. Employment in industry has been fairly constant, fluctuating between a low of 10 percent between 1994 and 2000 and a high of 17 percent between 1973 and 1983. It is currently around 14 percent (Table 3.1), reflecting the relatively small and fluctuating role of industry in GDP.

Table 3.1-Employment by sector (percent of total), 1965-2006

\begin{tabular}{lccccc}
\hline & $\mathbf{1 9 6 5 - 1 9 7 2}$ & $\mathbf{1 9 7 3 - 1 9 8 3}$ & $\mathbf{1 9 8 4 - 1 9 9 3}$ & $\mathbf{1 9 9 4 - 2 0 0 0}$ & $\mathbf{2 0 0 1 - 2 0 0 6}$ \\
\hline Agriculture & 64.0 & 58.0 & 61.1 & 62.0 & 55.0 \\
Industry & 14.0 & 17.0 & 12.8 & 10.1 & 14.0 \\
Services & 22.0 & 25.0 & 26.1 & 27.9 & 31.1 \\
\hline
\end{tabular}

Source: World Development Indicators 2009.

Note: Employment by sector data 1960-1980 from Boateng 1997, in Aryeetey and Fosu 2002.

Nonagricultural self-employment is difficult to estimate. According to Ghana Statistical Service (GSS 2000, 2007), 34 and 38 percent of households had income from nonagricultural self-employment in 1998/99 and 2005/06, respectively. Considering rural households only, the shares were 30 and 34 percent, respectively, in these two time periods. ${ }^{4}$ Except for in large cities such as Accra and Kumasi, where 40 and 49 percent of households, respectively, have wage income from employment in the formal sector (private or public), opportunities for participating in formal-sector economic activities are small. Overall in the country, the share of the informal sector in total employment is estimated to be around 80 percent and is characterized by relatively high labor market flexibility and high employment insecurity (World Bank n.d.). This is a pattern common to many countries in SSA (Kingdon, Sandefur, and Teal 2006).

Between the 1980s and 1990s, Ghana experienced a sharp decline in public-sector employment and an increase in informal-sector employment. The decline in public-sector employment can be explained by structural adjustment that resulted in public-sector retrenchment and withdrawal of subsidies to loss-making public enterprises, while increases in informal-sector employment are linked to lack of job creation by formal industrial sectors. Indeed, Ghana appears to be in a phase of informalization, which includes "a shift within wage employment to lower paid jobs so average wage earnings may be falling even if wage rates for given types of jobs are not" (Kingdon, Sandefur, and Teal 2006). More recent evidence, however, suggests that between 1992 and 2000, public-sector employment increased by 39 percent and the share of the private sector in formal employment increased by 85 percent due in part to the improved performance of divested state-owned enterprises (SOEs), free zone projects, the Ghana

\footnotetext{
${ }^{4}$ Authors' calculation using GLSS4 and GLSS5 (GSS 2000, 2007).
} 
Investment Promotion Center (GIPC) investment program, and higher private-sector earnings (World Bank nd).

In common with other Sub-Saharan African countries, employment in Ghana has lagged behind growth in the working population: between 1984 and 2000, the labor force grew by 5.8 percent per year, economic growth averaged 4.5 percent per year, and employment in the formal sector grew at 3.1 percent (World Bank nd). Ghana's informal sector has absorbed much of the increase in labor supply such that recorded rates of unemployment are low (Kingdon, Sandefur, and Teal 2006). The unemployment rate has, however, increased from a low of 0.8 percent in 1988/89 to 10.4 percent in 2000. Unemployment rates were highest in Accra, at 16.6 percent. In contrast, unemployment in rural areas is much lower, at 5.5 percent. Ghana's relatively high level of unemployment among its most skilled labor force supports other evidence that Ghana does not have a relative skills shortage (Lejarra 2010). Between 1984 and 2000 , the total labor force participation rate dropped from 82.5 percent to 74.7 percent, reflecting an increase in the share of economically inactive population. In part, this change may be due to people continuing into higher education, as educational institutions offer free board and lodging in addition to free education (suggesting that individuals are being pushed into education because of a lack of economic opportunities; Aryeetey and Baah-Boateng 2007). 


\section{LINKAGES}

Economic transformation typically involves increasing linkages between agriculture, manufacturing, and services and between rural and urban economies. In this section we first explore the linkages between agriculture, manufacturing, and services in Ghana. We then address rural-urban linkages through migration and welfare differences across space.

\section{Linkages between the Sectors}

Both production and consumption linkages between sectors are important for growth, and they can be enhanced by promoting sectors with larger intersectoral linkages (Andrae 1981). Consumption linkages are particularly important in the early stages of transformation, when a majority of the population depends on agriculture for its livelihood (Mellor 1976).

Here we present a quantitative analysis of the production linkages between Ghana's agricultural, agroprocessing, other manufacturing, other industrial, and service sectors using the Ghana 2007 social accounting matrix (SAM) which is updated ${ }^{5}$ based on the country's 2005 SAM (IFPRI 2007) (Table 4.1). Our analysis demonstrates that manufacturing and its subcomponent, agroprocessing, has the strongest backward linkages, as each unit of production comprises 0.64 or 0.75 units of intermediate inputs, respectively. Ghana's agricultural sector, on the other hand, has the weakest backward linkages to the rest of economy, particularly to the industrial sector. This is not uncommon among African countries (Stryker and Dumenu 1986; Jebuni, Asuming-Brempong, and Fosu 1990; Ramatu and Egyir 2002), because agricultural production uses little intermediate input, which stimulates neither demand for industrial goods nor new investments in downstream activities (Delgado et al. 1998).

Table 4.1-Input-output relationship in 2007 (value of sector's output $=1.00$ )

\begin{tabular}{|c|c|c|c|c|c|c|}
\hline Input & Production & Agroprocessing & $\begin{array}{l}\text { Other } \\
\text { Manufacturing }\end{array}$ & $\begin{array}{l}\text { Other } \\
\text { Industry }\end{array}$ & Services & $\begin{array}{l}\text { Total Inputs } \\
\text { Used by Other } \\
\text { Sectors/Sector } \\
\text { Output }\end{array}$ \\
\hline Agriculture & 0.09 & 0.35 & 0.08 & & 0.01 & 0.13 \\
\hline Agroprocessing & & 0.12 & 0.00 & 0.00 & 0.01 & 0.08 \\
\hline $\begin{array}{l}\text { Other } \\
\text { manufacturing }\end{array}$ & 0.08 & 0.03 & 0.38 & 0.32 & 0.18 & 1.38 \\
\hline Other industry & 0.00 & 0.01 & 0.13 & 0.06 & 0.01 & 0.11 \\
\hline Services & 0.19 & 0.13 & 0.17 & 0.04 & 0.27 & 0.25 \\
\hline Total input & 0.36 & 0.64 & 0.75 & 0.42 & 0.50 & \\
\hline
\end{tabular}

Source: Authors' aggregation using Ghana SAM 2007.

Notes: The table can be interpreted as follows: Each number in the table represents a sector's use of intermediate inputs from the various sectors required to produce a unit of this sector's output (the units can be all normalized to a value term such as cedi). The last row of the table displays the total use of inputs per unit of output across sectors. For example, for each unit of agricultural product produced by Ghanaian farmers, the intermediate inputs account for 0.36 of that unit, including the inputs produced by the agricultural sector such as seeds, those produced by the manufacturing sector such as chemical inputs, and services. The final column shows how much of a sector's output becomes intermediate inputs in the other sectors.

The forward linkages of agriculture to other economic sectors are stronger than the sector's backward linkages. About 13 percent of agricultural products are employed as intermediate inputs by other economic activities, almost exclusively agroprocessing. Considering that agriculture is one of the largest production sectors in the economy and manufacturing is small, this percentage is reasonably high.

\footnotetext{
${ }^{5}$ For more discussion on the calibration of 2005 Ghana SAM to the new 2007 SAM, see Breisinger et al. 2010.
} 
However, not all inputs used in the other sectors are produced domestically. ${ }^{6}$ The input-output relationships are further weakened in Ghana when agricultural raw materials are exported directly or when processing becomes uncompetitive. We give two examples to illustrate this: cocoa and tomatoes. Even though the country has developed cocoa processing facilities - particularly under the Presidential Cocoa Processing Initiative - the capacity is significantly underused. Currently, less than 10 percent of cocoa bean is processed locally, although the value of processed cocoa-based exports increased from $\$ 255$ million in 2004 to $\$ 420$ million in 2008 (UN 2010). The low utilization of local processing capacity is because the Ghana Cocoa Board, or Cocobod, which has a monopoly over marketing, sees greater benefits to the sector from exporting high-quality beans that fetch a premium in global markets than from capital-intensive processing locally.

The linkage effect between agriculture and agroprocessing can be undermined by international competition. The tomato crop is one such case. Processed tomatoes are an important food item for Ghanaian households both in rural and urban areas. Fresh tomatoes are an important cash crop for many farmers in the country. Since the 1960s the government has made intermittent efforts to promote tomato processing by setting up three plants shortly after independence (Ablorh-Odjidia 2003; Robinson and Kolavalli 2010) and by refurbishing two of these processors through public-private partnerships in the recent years. However, domestic processing has not been competitive, because productivity and quality of fresh tomatoes are too low to ensure the processors a regular supply of tomatoes at a competitive price.

Now we turn our attention to consumption linkages in which farmers with increased income from agricultural growth increase their spending on nonagricultural goods and services. During the 1990s when the economy grew steadily, large increases in rural household expenditure reflected a large reduction in rural poverty, particularly for female-headed households. Some argue that this was due to rapid growth in the rural nonfarm sector that may not have been linked to the agricultural sector (Anriquez and Daidone 2008; Canagarajah et al. 2001). For example, between 1987/1988 and 1991/92, nonfarm self-employment increased its contribution to household income from 11.9 percent to 23.6 percent (Canagarajah, Newman, and Bhattamishra 2001). Overall, few linkages have been found between noncocoa farm and nonfarm activities in rural Ghana, reflecting in part nonfarm activities as risk-reducing strategies (Canagarajah, Newman, and Bhattamishra 2001).

However, cocoa does appear to have had a larger impact on economic transformation in Ghana through consumption linkages. Ghana's cocoa farmers have fared better than the agriculture-dependent population as a whole. Household surveys indicate that poverty among cocoa-producing households has dropped to 23.9 percent in 2005, down from 60.1 percent at the beginning of the 1990s (World Bank 2007, Vol. 3). Jedwab (2011) finds evidence that linkages to the consumption of cocoa have driven urbanization in the cocoa belt, resulting in a rise of consumption cities driven by farmers, traders, and providers of other services, and based on agriculture and nontradable services. These cities have less manufacturing and are less economically diversified than "production" cities and may not hold as much potential for sustained accelerated growth. The consumption linkage of cocoa also partly explains why Ghana has experienced relatively high levels of urbanization within the cocoa belt but without economic agglomeration.

\section{Rural-Urban Linkages}

An important element of economic transformation is the movement of people and resources out of agriculture and rural areas and into services and industry in urban areas. In the initial stages, households may not move out of rural areas but rather have some members participating in nonfarm activities in rural areas. By the metrics of diversification and migration, Ghana's rural areas have experienced transformation. Ghana's rural households have diversified their livelihoods through rural to urban migration and through their increasing participation in the rural non-farm economy. But rural Ghana's diversification and migration appear to be more in response to distress rather than in response to new and improved non-farm opportunities (Ellis and Freeman 2004). Indeed, only asset-rich households appear to

\footnotetext{
${ }^{6}$ The ratio greater than 1 (for other manufacturing) indicates that the demand for other manufacturing products as intermediates is more than the production capacity of the country, and such demand has been met by imports.
} 
have successfully diversified in Ghana whilst asset-poor households tend to be pushed into non-farm activities to meet subsistence needs (Lay and Schuler 2007).

\section{Internal Migration}

In Ghana, migration is due to both push and pull factors. Internal migrants are younger, less educated, and more likely to be male than the general adult population (Ackah and Medvedev 2010). Most migration has been from the rural to urban south with more than two-thirds of internal migrants coming from the southern regions and just 10 percent from the poorer three northern regions. Internal migrants account for only 3 percent of the population in two of the three northern regions and 8 percent in the third. In the Ashanti and Western regions, on the other hand, migrants account for more than 10 percent of the population (and a quarter of the adult population over 15) and in Accra more than 18 percent of the total population and 26 percent of the adult population (Ackah and Medvedev 2010). Overall, 75 percent of migrants come from rural areas and of these around 67 percent migrate to an urban area (World Bank 2010). ${ }^{7}$

The migration that does occur from the poorer rural north to the richer urban south is driven primarily by push factors rather than by economic opportunities. Additionally, the number of migrants is small, and those who do migrate from the north do not do as well economically as those who migrate from the south (World Bank 2010). These data suggest that north-south migration has not played a key role in poverty alleviation.

\section{Differences in Access to Services and Patterns of Poverty}

The government of Ghana has made significant efforts to support Ghana's rural areas, with investment in basic infrastructure (roads, water, and electricity) partly with the aim of encouraging people to stay in rural areas rather than migrate to the cities (Asmah 2011). A sustained rural electrification program has provided an increase in the access to electricity in rural areas from 8.7 percent of households in 1991/92 to 27 percent in 2005/06. 65 percent of rural households now have access to potable water, and 88 percent for urban areas.

Fundamental differences in geography and ethnic diversity have been found to have important effects on local public service provision in Ghana (Akramov and Asante 2009). Districts in the coastal and forest zones have better access to local public services; and the more ethnically diverse a district, the lower the level of access to public services, including drinking water. Explanations for the role of ethnic diversity include differences in tastes and preferences over the types of public goods, weak social capital, and local institutions that manage interethnic relations.

Increasingly, Ghana's poor can be found in cities, although the poverty rates are low simply because the urban population has become relatively large. The poverty rate has been increasing even in Accra in recent years, driven mainly by migration from other regions and the inability of the city's economy to accommodate all the migrants (Coulombe and Wodon 2007). Even so, most of Ghana's poor still live in the less economically developed northern part of the country (Table 4.2).

In Ghana, the overall growth in inequality at the country level has been less pronounced than in many other African countries (Breisinger and Diao 2008). Within the country, poverty reduction has been spatially uneven: poverty is consistently lower in urban areas and consistently lower in the south. The most rapid reduction in the proportion of the poor has occurred in the rural south. This poverty reduction has been attributed to a combination of rural development and urbanization, including income creation outside of agriculture, predominantly in informal employment (World Bank 2010, 2007, 2009).

\footnotetext{
${ }^{7}$ Of the 25 percent of migrants that come from urban areas, 83 percent go to a different urban area.
} 
Table 4.2-Percentage of population classified as poor by location

\begin{tabular}{llll}
\hline & $\mathbf{1 9 9 2}$ & $\mathbf{1 9 9 9}$ & $\mathbf{2 0 0 6}$ \\
\hline Urban north & 45.4 & 50.3 & 31.3 \\
Rural north & 74.2 & 82.4 & 68.5 \\
Overall north & 68.8 & 76.6 & 62.7 \\
Urban south & 25.7 & 16.1 & 8.9 \\
Rural south & 60.6 & 40.2 & 28.2 \\
Overall south & 47.9 & 31.3 & 19.8 \\
\hline
\end{tabular}

Source: Adapted from World Bank 2010 from GLSS data.

In Ghana there is a strong correlation between regional poverty and access to infrastructure. Districts that have poor access to infrastructure also have lower welfare levels. Ghana's northern regions stand out in a number of dimensions, being poorer, less well educated, and less well connected to markets. Little urbanization has occurred in the north-indeed, between 1992 and 2006, the urbanization rate in the north actually declined from 19 percent to 16 percent. But per capita public expenditures in Ghana are not statistically different between districts in the north and south, due possibly to the national government's fiscal equalization policy (Akramov and Asante 2009). ${ }^{8}$

Barriers to integration between Ghana's north and south include weak infrastructure connectivity (roads, communication), regulatory barriers to trade and entry, lack of human and physical capital portability, and ethnic and linguistic divisions (World Bank 2010). This north-south divide can also be found in firm size and productivity, again reflecting poor connectivity, with northern-based firms more likely to have evolved from the informal sector and with north and south firms often using different production technologies.

\footnotetext{
${ }^{8}$ This is different from what is found, for example, in Côte d'Ivoire, where the spatial pattern of poverty differs-in particular, there is not such a strong north-south poverty divide, which has been attributed to more effective public service provision throughout the country and a surge in cashew nut exports (World Bank 2010). Overall, however, Côte d'Ivoire has experience considerably less overall poverty reduction (between 1993 and 2002) than Ghana.
} 


\section{LOCATION OF POPULATION AND ECONOMIC ACTIVITIES}

\section{Location of Population}

Rural and urban are often defined by political status and administrative boundary; concentration of economic activities is not necessarily consistent with the defined urban areas. In this analysis, we apply the agglomeration index (AI) developed by Uchida and Nelson (2010) to provide an alternative to the United Nations' measure of urban concentration. This index is based on three factors: population density, population size of contiguous urban areas, and travel time to the urban center. While we consider different sizes of urban agglomerations with different thresholds for the total number of population in contiguous urban areas, we choose uniform measures for the other two factors. The threshold of population density to distinguish urban from rural is a population per square kilometer of at least 150 people, and the threshold for the travel time is one hour or less.

We consider two sizes of urban agglomerations: large urban is defined as having a population of more than 500,000, and medium urban between 50,000 and 500,000. Additionally, Ghana has about 100 small towns with an urban population of 5,000-50,000 that we do not consider as agglomerations. With this definition, 37.2 percent of the population was living in urban areas in 2001, including 8.3 percent in small towns (see Appendix Table A.1). This share of urban population is significantly lower than that defined by the United Nations, which was 45 percent in 2001 (World Bank 2009d). ${ }^{9}$

In distinguishing rural from urban, it is useful to understand the linkages between the two. On the basis of physical connectivity to the urban agglomeration centers - reflected by travel time or condition of roads - we break down rural areas into urban peripheries and rural. Urban peripheries are rural areas with a similar travel time to the closest urban agglomeration centers as areas within the urban agglomerations. What makes them different from urban agglomeration is lower population density, below the threshold of 150 per square kilometer. Urban peripheries also include areas close to the urban agglomeration with population density as high as in the urban agglomeration but without physical connection with the closest urban agglomerations. All other rural areas that do not meet the above two conditions-with travel time to the agglomeration centers longer than an hour and population density lower than 150 per square kilometer-are defined as rural.

Figure 5.1 shows Ghana's key urban agglomerations and peripheries (Appendix Tables A.1, A.2, and A.3 provide summaries of population and population density). The largest urban category has only two mega urban agglomerations, Accra and Kumasi, each with a population of more than 1.5 million. The majority of Ghana's urban population (about 56 percent) lives in these two large agglomerations with extremely high population density (2,500 per square kilometer). The medium urban category comprises 10 smaller urban centers with a population of 50,000-500,000, where 22 percent of the urban population lives, and with an average population density of 626 per square kilometer. The small towns in total have 8.3 percent of the national urban population.

\footnotetext{
${ }^{9}$ We compare with 2001 in WDI because the population data we used in the analysis is from Landscan 2002.
} 
Figure 5.1-Urban agglomerations and their periphery areas

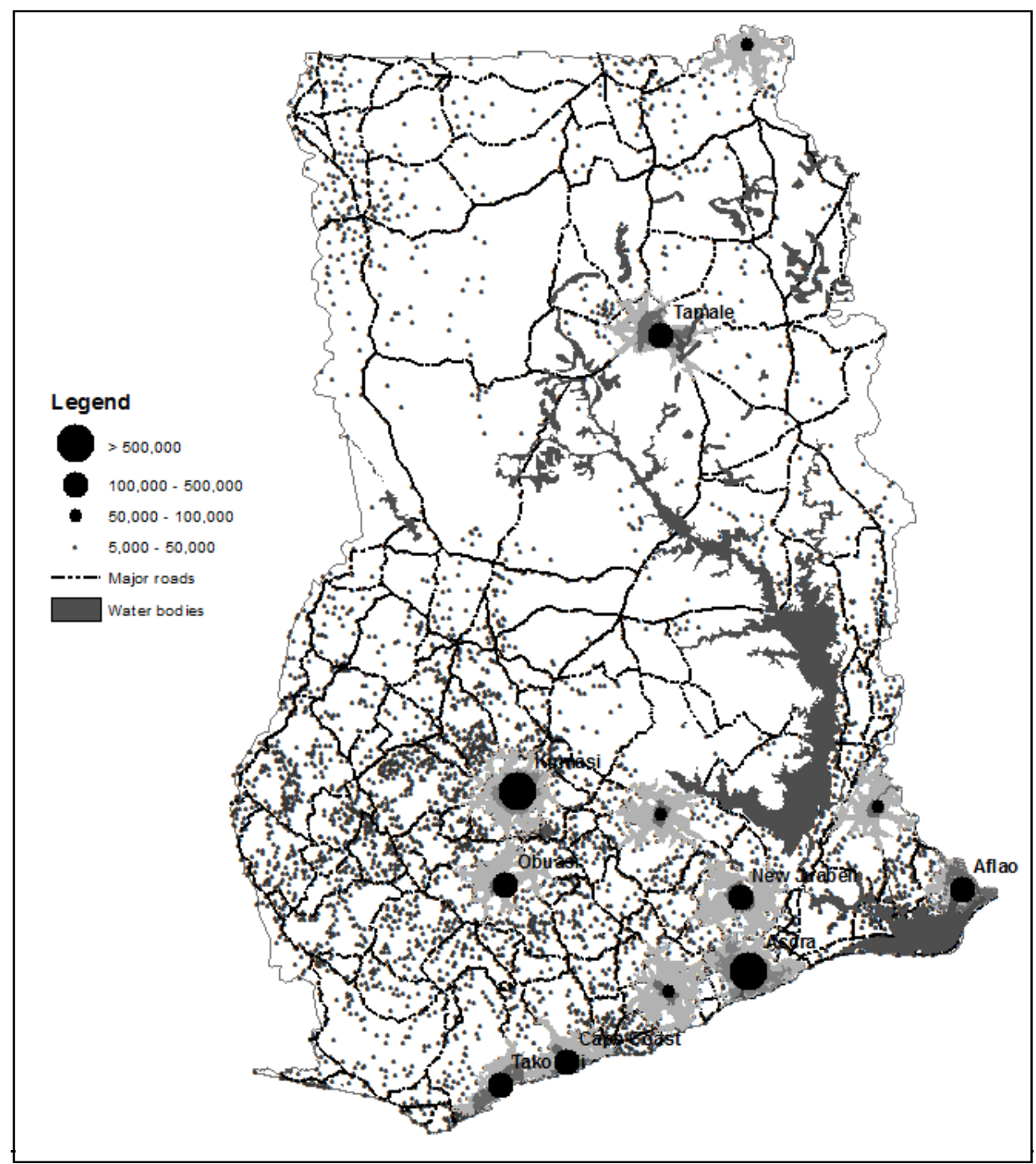

Source: Authors' calculation using agglomeration index method. The population data are from 2002 Landscan developed by Oak Ridge National Laboratory and the road data are provided by a research partner in Ghana.

Notes: The largest dot corresponds to largest urban agglomeration namely Accra and Kumasi with population of more than 500,000. The second largest agglomerations with population between 100,000 to 500,000 include: Takoradi, Cape Coast,Aflao in the coastal; New Juaben and Obuasi in the southern; and Tamale in the northern areas. The dark shade surrounding the dot is the urban boundary and the lighter shade that surrounds this urban boundary is the urban periphery area.

Around the urban agglomerations are vast areas, that is, urban peripheries, which are well connected but have lower population density. About 10 percent of the national population lives in the urban periphery areas with a geographic area three times the size of the urban agglomerations, indicating the potential for urban expansion. Although the population density is still lower, at an average of 147 per square kilometer in such areas, it is much higher than that in rest of the rural areas ( 52 per square kilometer). Relatively high population density and better connection with urban centers in the urban periphery areas offer these areas more opportunities to develop economic activities both in the agricultural and nonagricultural sectors that can better take advantage of urban agglomerations. For example, urban peripheries have the potential to develop intensive farming systems in high-value agriculture and agroprocessing to link agriculture with urban demand. 


\section{Location of Economic Activities}

In this subsection we examine whether economic activities are related to agglomeration by examining sources of household nonfarm incomes using the GLSS surveys, which include the industrial classification of the occupations and incomes. It is not possible to locate the households surveyed in each GLSS within districts, so we place the districts into the three agglomeration categories identified above. We investigate the role of nonagricultural income among different household groups by adopting the definition developed by Carletto et al. (2007), in which wage income and self-employment income are identified separately. In the following tables and figures, large urban represents both the large urban agglomerations and their periphery areas, but we often report their income structure separately. Similarly, medium urban represents medium urban agglomerations and their periphery areas. We aggregate all remaining households into small town, which represents the rest of the urban and the majority of rural areas of the country. In each of the three categories, we consider two types of households, rural and urban, which are defined in the Ghana Living Standards Survey (GLSS). That is, urban households in the three locations are residents living either in cities or in towns, while rural households live either in the urban peripheries (in the cases of large urban and medium urban) or in the rest of rural areas.

We first discuss proportions of households that earn income from nonagricultural sources in total households by location and household type in Table 5.1. All households considered together, opportunities to earn incomes from nonagricultural sources have increased: 56 percent of households reported nonagricultural income in 2005/06 compared with 50 percent in 1998/99. The share of households earning nonagricultural incomes increases with the agglomeration size. Over time, the share of households earning nonagricultural incomes increased in large urban and small town but barely changed in medium urban. Thus, the differences in nonagricultural opportunities between medium urban and small town are becoming smaller.

We focus on whether urbanization also affects the livelihood of rural households. To answer this question, we need to further distinguish households by rural and urban types at the three locations in Table 5.1. The second panel of the table shows the percentage of urban households that reported nonagricultural income, and the third panel shows that for the rural households. As shown in the second panel, not all urban households have income from nonagriculture. In 1998/99, about 56 and 54 percent of medium agglomeration and small town urban households, respectively, reported nonagricultural income. For the country as a whole, 64 percent of total urban households had nonagricultural income. In 2005/06, more urban households reported nonagricultural income (71 percent of total urban households), and the percentage of such type of households consistently increased in all locations in 2005/06.

By definition, rural households should have fewer nonagricultural opportunities than the urban households have. This is true at the national level, as about 41-44 percent of total rural households, versus 64-71 percent of total urban households, had nonagricultural income in the two surveys (Table 5.1, second and third panels). Rural households living in the medium urban periphery areas seem to have had more opportunities to participate in nonagricultural activities in 1998/99 than in the other locations (52 percent, versus 33-36 percent in other locations). However, such advantage for medium urban disappeared in 2005/06, as the difference in the percentage of rural households that reported nonagricultural income became insignificant between medium urban and small town (Table 5.1, third panel). This is most likely because mining areas are part of medium urban locations, where many rural households live in the peripheries and earned income from mining. Such opportunities obviously declined in the recent years. On the other hand, many more rural households living in the large urban peripheries reported nonagricultural income in the recent survey (48 percent, 2005/06) than in the early one (33 percent, 1998/99). 
Table 5.1-Percentage of households with nonagricultural income by location and type of households

\begin{tabular}{lrr}
\hline & $\mathbf{1 9 9 8 / 9 9}$ & $\mathbf{2 0 0 5 / 0 6}$ \\
\hline Total & 49.8 & 55.5 \\
Large urban & 64.0 & 68.8 \\
Medium urban & 53.3 & 53.5 \\
Small town & 39.6 & 48.3 \\
\hline & & \\
Urban & 63.5 & 71.0 \\
Large urban & 70.6 & 75.4 \\
Medium urban & 56.2 & 68.5 \\
Small town & 54.2 & 64.8 \\
\hline & & \\
Rural & 40.6 & 43.8 \\
Large urban & 33.0 & 48.1 \\
Medium urban & 51.8 & 44.2 \\
Small town & 36.1 & 42.7 \\
\hline
\end{tabular}

Source: Authors' calculations using GLSS4 and GLSS5 (GSS 2000, 2007).

Note: The number of different type of households in different locations totals 100 .

Household income structure has changed with urbanization. Table 5.2 displays such change in detail by shares of income from agriculture, nonagriculture, and other sources by locations ${ }^{10}$. At the national level, agricultural income was about one-third of total household income in 1998/99, and the proportion decreased to 19 percent in 2005/06. The declining share of total agricultural income was replaced by nonagricultural income primarily from self-employment, while the share of wage income increased modestly and the share of "other income," predominantly transfers, changed little between the two surveys. By location, it is surprising that households living in small towns experienced the most rapid decline in their share of agricultural income: in 1998/99, 57 percent of their total income came from agriculture, but by 2005/06 this was reduced to 30 percent (Table 5.2, first panel).

The second and third panels of Table 5.2 distinguish households by urban and rural types at the three locations, and we focus the discussion on the rural households. In 1998/99, agriculture provided rural households with 55 percent of their total income; this share fell to 36 percent in 2005/06. In other words, agriculture is no longer the main income source for Ghanaian rural households as a whole or for them as groups in three different locations. It is understandable that urbanization should first benefit rural households living close to the large urban centers. Thus, it is not surprising to see that the most rapid changes in rural household income structure are observed in the large urban periphery areas, where agricultural income provided only a quarter of their total income in the recent survey, a drop from 50 percent in 1998/99. However, the rapid decline in the agricultural income share for the rural households classified into small towns is hard to explain by the agglomeration effect. Table 5.2 (the last row) shows that in the recent survey (2005/06) agriculture accounted for only 40 percent of total income for rural households not living in large and medium peripheries. In contrast, in the early survey (1998/99), agriculture was the dominant income source for these households, accounting 62 percent of their total income. Factors causing rapid income structure change among rural households, particularly those not living in urban peripheries, deserve further investigation, which is beyond the scope of this paper.

\footnotetext{
${ }^{10}$ Agriculture income sources include earnings from growing crops and livestock and agricultural wage employment; nonagriculture income comes from non-farm wage employment and non-farm self-employment; others include transfers and other sources.
} 
Table 5.2-Share of agricultural and nonagricultural income in household total income

\begin{tabular}{|c|c|c|c|c|c|c|c|c|}
\hline & \multicolumn{4}{|c|}{$1998 / 99$} & \multicolumn{4}{|c|}{$2005 / 06$} \\
\hline & \multicolumn{4}{|c|}{ Nonagriculture } & \multicolumn{4}{|c|}{ Nonagriculture } \\
\hline & Agriculture & Wage & $\begin{array}{c}\text { Self- } \\
\text { employment }\end{array}$ & Others & Agriculture & Wage & $\begin{array}{c}\text { Self- } \\
\text { employment }\end{array}$ & Others \\
\hline Total & 33.2 & 21.8 & 36.3 & 8.7 & 19.0 & 25.1 & 48.5 & 7.4 \\
\hline Large urban & 10.0 & 29.9 & 48.4 & 11.7 & 6.2 & 32.9 & 52.4 & 8.4 \\
\hline Medium urban & 33.0 & 23.1 & 35.4 & 8.5 & 21.6 & 22.9 & 48.6 & 7.0 \\
\hline Small town & 56.9 & 12.8 & 24.4 & 5.8 & 29.7 & 19.1 & 44.7 & 6.6 \\
\hline Urban & 11.9 & 31.4 & 45.6 & 11.1 & 5.6 & 33.8 & 52.4 & 8.1 \\
\hline Large urban & 5.4 & 32.8 & 50.2 & 11.6 & 2.2 & 36.4 & 53.0 & 8.3 \\
\hline Medium urban & 19.5 & 33.0 & 37.2 & 10.3 & 7.1 & 34.9 & 49.5 & 8.4 \\
\hline Small town & 35.0 & 22.8 & 32.6 & 9.6 & 11.7 & 27.1 & 53.7 & 7.5 \\
\hline Rural & 54.7 & 12.2 & 26.8 & 6.3 & 36.1 & 14.0 & 43.5 & 6.4 \\
\hline Large urban & 49.7 & 5.0 & 33.3 & 12.1 & 25.2 & 16.2 & 49.7 & 8.9 \\
\hline Medium urban & 40.2 & 17.8 & 34.4 & 7.5 & 34.6 & 12.0 & 47.7 & 5.7 \\
\hline Small town & 62.1 & 10.5 & 22.5 & 4.9 & 39.8 & 14.5 & 39.5 & 6.1 \\
\hline
\end{tabular}

Source: Authors' calculations using GLSS4 and GLSS5 (GSS 2000, 2007).

Notes: The total income is 100 for each individual group.

Comparing the share of nonagricultural household income (Table 5.2, third panel) with the share of households that have nonagricultural income (Table 5.1, third panel) shows that both have increased, but far from equally. Nonagricultural income is becoming a dominant income source, but it is not increasing equally among rural households. To illustrate this, Table 5.1, panel three, shows that 44 percent of total rural households had nonagricultural income in 2005/06, a small increase from 40 percent in 1998/99. On the other hand, in Table 5.2, panel three, 64 percent of rural household income was from nonagricultural sources in 2005/06, a marked increase from 46 percent in 1998/99. To put it another way, in 2005/06, nonagricultural income supplied 44 percent of total rural households with 64 percent (nearly two-thirds) of their income; in 1998/99, nonagricultural income supplied 40 percent of rural households with 46 percent (less than half) of their income. This finding seems to indicate that rural households are unlikely to have similar nonagricultural opportunities. Only 4 percent more rural households had such opportunities in 2005/06 than in 1998/99. However, for those whose nonagricultural income increased, it grew much more rapidly than their agricultural income, allowing their share of nonagricultural income to increase by 18 percent.

We now turn to the structure of nonagricultural income. GSS data show that nonagricultural income is mainly from informal sources. Firm-level studies show that agglomeration can create economies of scale (see, for example, Melo, Graham, and Noland 2009, for a literature review), and one might expect a proliferation of formal firms in agglomerations. However, the Ghana data at the household level suggest that most nonagricultural income comes from informal sources, which are captured as nonfarm self-employment income in the surveys. As shown in Table 5.2, panel one, wage income accounted for 22 percent of total income for all households as a whole in 1998/99, and this share increased modestly to 25 percent in 2005/06. On the other hand, the share of self-employment income in total income increased from 36 percent in 1998/99 to 49 percent in 2005/06. Moreover, this trend is consistently seen in all three locations for both rural and urban households.

Moreover, services dominate nonagricultural income from both wages and self-employment activities. We consider two groups of households for the investigation. We first consider households with 
only wage income and investigate their nonagricultural income structure. In GLSS5 (2005/06), only 18 percent of total households in the country have nonagricultural wage income. In the large agglomerations, households with nonagricultural wage income account for 31 percent of total households, and the percentage is 14 and 12 percent, respectively, in the medium agglomerations and small town locations (Table 5.3, panel one, first column). We then calculate the shares of income from manufacturing and services for these households. As shown in the first panel of Table 5.3 (second and third columns), manufacturing accounts for 13 percent of total wage income for wage-earning-only households and services account for 73 percent. Although location does not affect the share of services in total wage income, manufacturing income becomes much less important for wage-earning households living outside large urban agglomerations ( 8 and 7 percent in medium and small, compared with 18 percent in large agglomerations). This suggests that manufacturing, in which agroprocessing is an important subsector in Ghana, may be concentrated in large agglomerations. Firms in the large cities may benefit from agglomeration effects, with much higher fixed capital costs and labor costs in such locations; however, experiences of other countries show that potential for future development of such manufacturing in large urban centers is rather limited.

In the second panel of Table 5.3, we investigate the structure of informal nonagricultural household income. Households with informal nonagricultural income may also have formal wage income, but they have to have informal income as part of nonagricultural income (that is, the two groups of households in the two panels of Table 5.3 are not mutually exclusive). In total, 38 percent of households in 2005/06 are characterized as households with informal nonagricultural income; locations seem not to matter much for this percentage. For households with informal income, services still dominate their nonagricultural income, and the service shares of total nonagricultural income (around 70 percent) are also similar with that for the wage-earning household groups (in the first panel of Table 5.3). However, in this case, the manufacturing share is much higher in the locations outside large urban agglomerations than inside. Formal manufacturing is concentrated in large agglomerations, while informal manufacturing, such as gari and kenke making, is somewhat higher in small and medium agglomerations.

Table 5.3-Shares of manufacturing and services in total nonagricultural income, 2005-2006

\begin{tabular}{|c|c|c|c|c|}
\hline \multicolumn{5}{|c|}{ Households with Wage Income Only } \\
\hline & \% of Group's & \multicolumn{2}{|c|}{$\%$ of Nonagricultural Income } & \multirow[b]{2}{*}{ Others } \\
\hline & Households & Manufacturing & Services & \\
\hline Total & 18.0 & 13.0 & 73.2 & 13.8 \\
\hline Large urban & 31.1 & 18.2 & 69.5 & 12.3 \\
\hline Medium urban & 13.9 & 8.4 & 79.7 & 12.0 \\
\hline Small town & 11.9 & 7.4 & 74.7 & 17.9 \\
\hline \multicolumn{5}{|c|}{ Households with Self-Employment Income } \\
\hline & \multirow{2}{*}{$\begin{array}{c}\% \text { of Group's } \\
\text { Total } \\
\text { Households }\end{array}$} & \multicolumn{3}{|c|}{$\%$ of Nonagricultural Income } \\
\hline & & Manufacturing & Services & Others \\
\hline Total & 37.6 & 23.0 & 72.7 & 4.3 \\
\hline Large urban & 37.7 & 17.0 & 79.5 & 3.6 \\
\hline Medium urban & 39.5 & 26.1 & 70.2 & 3.8 \\
\hline Small town & 36.4 & 28.1 & 66.4 & 5.5 \\
\hline
\end{tabular}

Source: Authors' calculation using GLSS5 (GSS 2007).

We next consider what kinds of service activities have provided households with nonagricultural opportunities. Again, we focus on the two groups of households that are classified in Table 5.3 for such analysis. As we show in Table 5.3, for both groups of households, services provide more than 70 percent of total nonagricultural income. Among the wage earners, nearly 60 percent of their service-related 
income is from working for government and other public-sector jobs such as government administration, education, and health (Figure 5.2). About one-quarter (24 percent) of their service-related income is in business-related occupations such as transport, storage, communication, finance, insurance, and real estate. Commerce including trade, hotel, and restaurants accounts for 16 percent (Figure 5.2). On the other hand, for the group that is self-employed, their service-related income is largely from commerce, 90 percent in total (Figure 5.3).

Figure 5.2-Structure of wage service income (for households with wage income as a group)

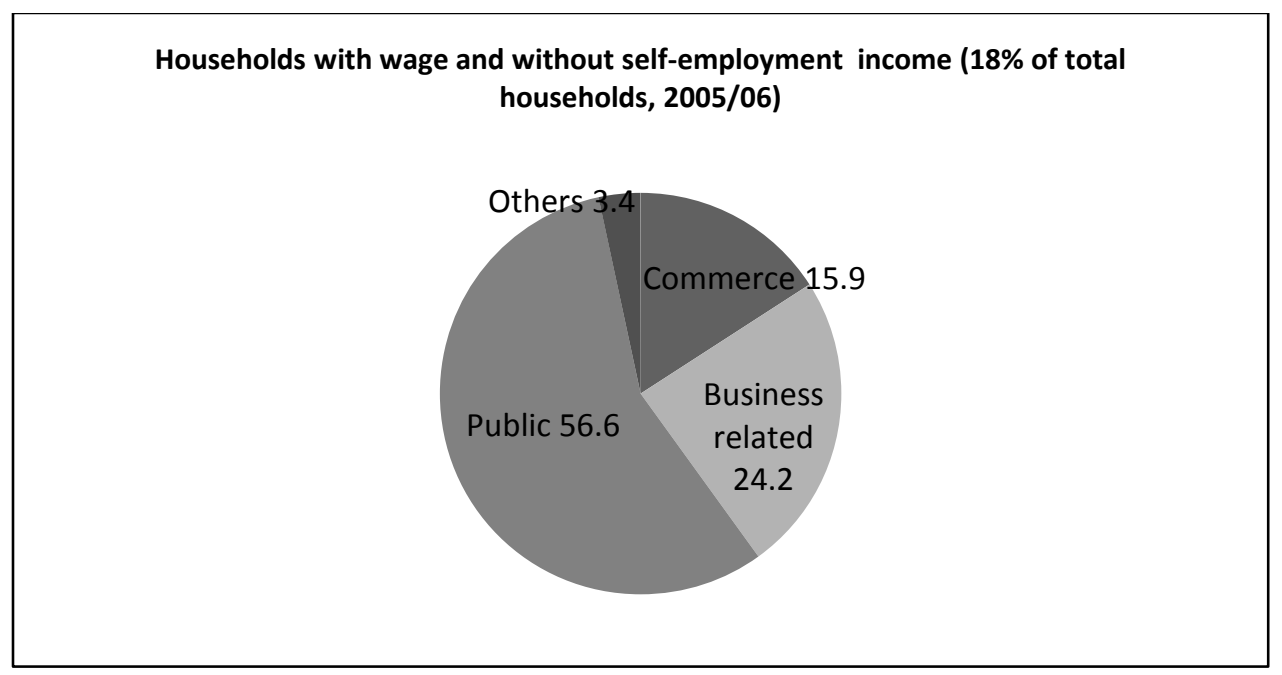

Source: Authors' calculations using GLSS5 (GSS 2007).

Note: $\quad$ Service income $=100$.

Figure 5.3-Structure of self-employment service income (for households with self-employment income as a group)

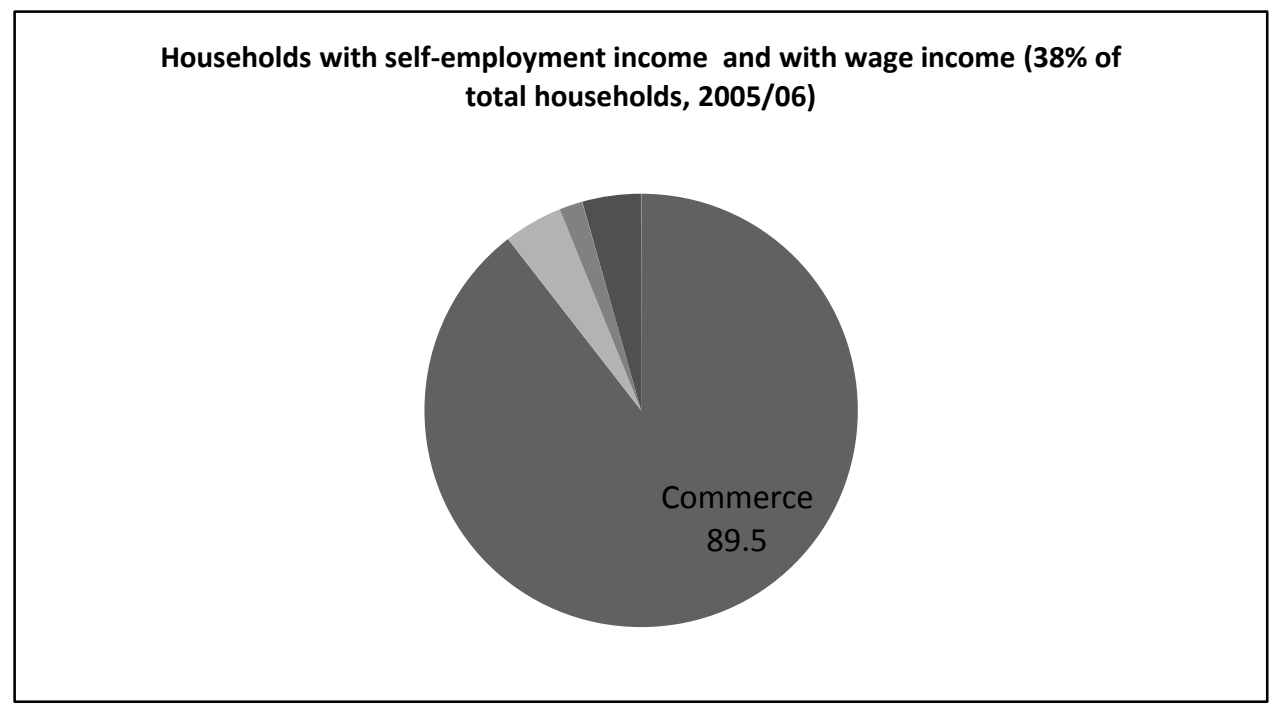

Source: Authors' calculations using GLSS5 (GSS 2007).

Note: $\quad$ Service income $=100$.

In summary, the findings of this section indicate that urbanization in general, and urban agglomerations in particular, have indeed created more nonfarm income opportunities, as the share of nonfarm income increased over time for households, regardless of location. The share of income 
increased is significantly higher for the households living in the large urban agglomerations and their peripheries than for those in the other locations. However, the impact of agglomerations in creating nonagricultural opportunity seems to concentrate only in large urban agglomerations, while the same opportunities for those in medium-size agglomerations are rather limited. Nonfarm self-employment activities, which are small in nature, are the dominant sources of nonagricultural income, regardless of the size of agglomeration. Agglomerations have primarily created commerce- and consumption-related nonfarm activities, and the service sector, whether formal or informal, has been far more important than manufacturing. In Ghana, this agglomeration and its economic implication are more related to the clustering of people - creating a potential consumption market for goods and services - rather than the clustering of manufacturing that offers agglomeration benefits in production. This conclusion is consistent with the stylized facts discussed in Section 2 at the sector level, that the role of the manufacturing sector in the economy has been stagnant over time and the declining agricultural share of GDP has been replaced by services. 


\section{CONCLUSIONS}

To conclude this study, we return to the three key issues that we highlighted at the start of this paper: economic structure and location, the role of agriculture in economic transformation, and patterns of urbanization and agglomeration. Economic transformation typically involves a declining share of agriculture in economic output and employment, a rising share of the population in urban areas, and an increase in the contribution of industry and services to economic growth. Under these metrics, Ghana's economy has been transforming while it has reached middle-income status.

However, Ghana has not taken the path taken by most successfully transformed countries in Asia and Latin America. Ghana's reduced share of agriculture in the economy has been filled by services, while manufacturing has stagnated and even declined. Inadequate agricultural transformation may be a reason. A rapidly transforming agricultural sector can help the transformation of other sectors through linkages. But Ghana has not experienced the kind of agricultural productivity growth that can drive the development of competitive agroprocessing industries. Also, Ghanaian agriculture, which is characterized by slow technology adoption, has limited demand for intermediate inputs from other sectors.

Ghana is one of the more urbanized countries in Africa, but its urban economic activities are dominated by those that benefit little from economies of scale or agglomeration. Consumption cities are emerging as a result of cocoa and gold export revenues, remittances from migrants, and foreign aid. This situation puts the exchange rate under tremendous upward pressure to become overvalued, which further disadvantages the development of tradable sectors other than cocoa and gold in both agriculture and manufacturing. As a result, economic growth in Ghana has become increasingly consumption driven, and structural change in terms of nonagricultural employment opportunities and household livelihood choices is led by development of services, mostly informal. This type of transformation weakens production linkages in particular.

Two factors seem critical from the experience of Ghana's economic transformation. The first is the weak transformation of the agricultural sector itself. Apart from the even stronger role the agricultural sector could have played in reducing poverty in the country, it appears to have constrained the development of competitive agroprocessing for the potential domestic market that is currently met from imports. Increasing productivity in smallholder agriculture has been a challenge. The current government development plans - to develop larger-scale commercial agriculture, to use it as a basis to support smallholder agriculture, and to invest in irrigation - may offer the potential to make significant progress in transforming agriculture. The second critical factor is the conditions faced by manufacturing in Ghana, apart from the supply of raw materials discussed earlier. A number of factors are cited in this paper as being hindrances. An issue then is whether Ghana needs an industrial policy and has done enough or made the necessary investments to encourage manufacturing. The country did attempt an industrial policy dominated by the state-owned enterprises immediately after independence, which failed for expected reasons associated with larger state failures. Whether there is a suitable environment for the private sector to lead manufacturing, and what kind of investments and other interventions the state needs to make to improve competitiveness, remain the challenging questions.

Regarding the location of economic activities, transformation involves the movement of people from agricultural to nonagricultural urban activities. In this process, the value added per worker in agriculture may increase, reducing poverty among those in the rural areas that depend primarily on agriculture for their livelihoods. While this strengthens the role of agriculture in reducing poverty, it can occur as a consequence of people being pushed out of agriculture rather than due to an increase in agricultural productivity. Without increasing land productivity, the implications of labor withdrawal on agriculture remain to be seen.

The difficulties faced by agroprocessing in the country suggest that more competitive agriculture in this country can contribute more to economic transformation. Ghana's transformation differs from many Asian countries; along its transformation path, how to compete in the domestic market for both agriculture and manufacturing and how to develop productive, tradable services seem to be two key factors in the success of Ghana's transformation. 


\section{APPENDIX A: SUPPLEMENTARY TABLES}

Table A.1-Population and population density by different agglomeration categories

\begin{tabular}{|c|c|c|c|c|c|c|c|c|c|c|c|c|}
\hline & \multicolumn{3}{|c|}{ Population (in thousands) } & \multicolumn{3}{|c|}{ Population share (\%) } & \multicolumn{3}{|c|}{ Area $\left(\mathrm{km}^{2}\right)$} & \multicolumn{3}{|c|}{ Population density (people $/ \mathrm{km}^{2}$ ) } \\
\hline & Urban & Periphery & Rural & Urban & Periphery & Rural & Urban & Periphery & Rural & Urban & Periphery & Rural \\
\hline $\begin{array}{l}\text { Large urban (urban } \\
\text { population }>500 \mathrm{k}\end{array}$ & 3,961 & 564 & & 20.7 & 2.9 & & 1,561 & 2,035 & & 2,537 & 277 & \\
\hline $\begin{array}{l}\text { Medium urban (urban } \\
\text { population } 50 k-500 k \text { ) }\end{array}$ & 1,560 & 1,279 & & 8.2 & 6.7 & & 2,491 & 10,505 & & 626 & 122 & \\
\hline $\begin{array}{l}\text { Small towns and rest of } \\
\text { the country }\end{array}$ & 1,594 & & 10,167 & 8.3 & & 61.5 & 1,923 & & 196,979 & 829 & & 52 \\
\hline Total & 7,116 & 1,843 & 10,167 & 37.2 & 9.6 & 61.5 & 5,976 & 12,540 & 196,979 & 1,191 & 147 & 52 \\
\hline
\end{tabular}

Source: Authors' calculations using agglomeration index and Landscan data 2000. 
Table A.2-Number of households classified in different locations and agglomeration categories

\begin{tabular}{|c|c|c|c|c|c|c|c|c|c|c|c|c|c|}
\hline & \multicolumn{3}{|c|}{ Coast } & \multicolumn{3}{|c|}{ Other South } & \multicolumn{3}{|c|}{ North } & \multicolumn{3}{|c|}{ National } & \multirow{2}{*}{$\begin{array}{r}\text { National } \\
\text { Total }\end{array}$} \\
\hline & Urban & Periphery & Rural & Urban & Periphery & Rural & Urban & Periphery & Rural & Urban & Periphery & Rural & \\
\hline \multicolumn{14}{|l|}{ 1998/99 } \\
\hline Large urban & 839 & 20 & 0 & 380 & 320 & 0 & & & & 1,219 & 340 & 0 & 1,559 \\
\hline Medium urban & 440 & 539 & 0 & 140 & 440 & 0 & 80 & 120 & 0 & 660 & 1,099 & 0 & 1,759 \\
\hline Small urban/ rest of country & 20 & 0 & 220 & 460 & 0 & 1,440 & 60 & 0 & 480 & 540 & 0 & 2,140 & 2,680 \\
\hline Total & 1,299 & 559 & 220 & 980 & 760 & 1,440 & 140 & 120 & 480 & 2,419 & 1,439 & 2,140 & 5,998 \\
\hline \multicolumn{14}{|l|}{$2005 / 06$} \\
\hline Large urban & 1,272 & 30 & 0 & 643 & 390 & 0 & & & & 1,915 & 420 & 0 & 2,335 \\
\hline Medium urban & 449 & 450 & 0 & 225 & 480 & 0 & 180 & 345 & 0 & 854 & 1,275 & 0 & 2,129 \\
\hline Small urban/ rest of country & 90 & 0 & 285 & 714 & 0 & 1,755 & 150 & 0 & 1,229 & 954 & 0 & 3,269 & 4,223 \\
\hline Total & 1,811 & 480 & 285 & 1,582 & 870 & 1,755 & 330 & 345 & 1,229 & 3,723 & 1,695 & 3,269 & 8,687 \\
\hline
\end{tabular}

Source: Authors' aggregation using GLSS4 and GLSS5 (GSS 2000, 2007).

Table A.3 - Share of population in different locations and agglomeration categories

\begin{tabular}{|c|c|c|c|c|c|c|c|c|c|c|c|c|c|}
\hline & \multicolumn{3}{|c|}{ Coast } & \multicolumn{3}{|c|}{ Other South } & \multicolumn{3}{|c|}{ North } & \multicolumn{3}{|c|}{ National } & \multirow{2}{*}{$\begin{array}{r}\text { National } \\
\text { Total }\end{array}$} \\
\hline & Urban & Periphery & Rural & Urban & Periphery & Rural & Urban & Periphery & Rural & Urban & Periphery & Rural & \\
\hline $1998 / 99$ & 12.2 & 0.2 & 0.0 & 6.7 & 3.5 & 0.0 & & & & 18.8 & 3.7 & 0.0 & 22.5 \\
\hline Large urban & 5.8 & 9.2 & 0.0 & 1.9 & 6.5 & 0.0 & 1.9 & 2.8 & 0.0 & 9.6 & 18.5 & 0.0 & 28.0 \\
\hline Medium urban & 0.2 & 0.0 & 3.7 & 6.9 & 0.0 & 25.4 & 1.4 & 0.0 & 11.9 & 8.4 & 0.0 & 41.0 & 49.4 \\
\hline $\begin{array}{l}\text { Small urban/ rest of country } \\
\text { Total }\end{array}$ & 18.2 & 9.4 & 3.7 & 15.4 & 10.0 & 25.4 & 3.3 & 2.8 & 11.9 & 36.8 & 22.2 & 41.0 & 100.0 \\
\hline $2005 / 06$ & 14.2 & 0.4 & 0.0 & 5.6 & 4.6 & 0.0 & & & & 19.8 & 5.0 & 0.0 & 24.8 \\
\hline Large urban & 4.1 & 5.8 & 0.0 & 2.6 & 6.1 & 0.0 & 2.1 & 4.8 & 0.0 & 8.7 & 16.7 & 0.0 & 25.4 \\
\hline Medium urban & 1.0 & 0.0 & 3.1 & 8.8 & 0.0 & 23.4 & 1.1 & 0.0 & 12.4 & 10.9 & 0.0 & 38.9 & 49.8 \\
\hline Small urban/ rest of country & 19.2 & 6.1 & 3.1 & 17.0 & 10.8 & 23.4 & 3.2 & 4.8 & 12.4 & 39.4 & 21.8 & 38.9 & 100.0 \\
\hline Total & 12.2 & 0.2 & 0.0 & 6.7 & 3.5 & 0.0 & & & & 18.8 & 3.7 & 0.0 & 22.5 \\
\hline
\end{tabular}

Source: Authors' aggregation using GLSS4 and GLSS5 (GSS 2000, 2007). 
Table A.4-Share of self-employment income by location

\begin{tabular}{|c|c|c|c|c|c|c|}
\hline & \multicolumn{3}{|c|}{ 1998/99 (GLSS 4) } & \multicolumn{3}{|c|}{ 2005/06 (GLSS 5) } \\
\hline & Manufacturing & Other . industry & Services & Manufacturing & Other. industry & Services \\
\hline Large urban & 21.9 & 3.7 & 74.4 & 17.9 & 2.3 & 79.8 \\
\hline Coast & 22.0 & 5.8 & 72.2 & 19.2 & 1.9 & 78.9 \\
\hline Other south & 21.8 & 0.9 & 77.3 & 16.4 & 2.7 & 80.8 \\
\hline Medium urban & 23.4 & 4.6 & 72.0 & 32.6 & 2.8 & 64.6 \\
\hline Coast & 28.9 & 4.4 & 66.7 & 36.0 & 1.2 & 62.7 \\
\hline Other south & 12.4 & 6.2 & 81.4 & 37.6 & 6.3 & 56.1 \\
\hline North & 11.2 & 0.0 & 88.8 & 17.2 & 1.1 & 81.8 \\
\hline Small urban/rest of country & 27.8 & 3.0 & 69.2 & 31.9 & 1.4 & 66.6 \\
\hline Coast & 44.6 & 7.7 & 47.7 & 30.2 & 0.7 & 69.1 \\
\hline Other south & 27.7 & 2.5 & 69.8 & 30.7 & 1.4 & 68.0 \\
\hline North & 11.2 & 0.0 & 88.8 & 39.5 & 2.4 & 58.1 \\
\hline Total & 23.9 & 3.7 & 72.4 & 26.5 & 2.1 & 71.5 \\
\hline
\end{tabular}

Source: Authors' aggregation using GLSS4 and GLSS5 (GSS 2000, 2007).

Note: Total nonfarm self-employment income at different locations equals 100 . 


\section{APPENDIX B: CLASSIFICATION RULES TO DEFINE A HOUSEHOLD ACCORDING TO THE THREE AGGLOMERATION CATEGORIES}

We place individual districts of Ghana into the three agglomerations mentioned in Section 3 , as it is not possible to locate the households surveyed. The districts are classified using the following rules: (1) If a district contains certain numbers of pixels that belong to the large urban agglomeration, we define this district as part of the large urban category and group all urban and rural households in this district into urban and periphery, respectively. (2) If a district does not contain any pixel that belongs to large urban but has pixels belonging to medium urban, we define this district as part of the medium urban and group all urban and rural households in this district also into urban and periphery, respectively. That is, we do not allow a district to have rural households other than those in periphery if the district's urban households are part of large urban or medium urban. (3) The rest of the districts that do not have any pixel in either large urban or medium urban are grouped into small town plus rest of the country. In this case, the rural households are still called rural (that is, rural outside the periphery). For a few districts where the majority of households are urban and the majority of the areas are part of the large agglomerations according to the agglomeration analysis, we consider all households of such districts as urban households in both surveys. See Table A.2 for the number of households of GLSS4 and GLSS5 assigned to the three regions and three agglomeration classifications, while Table A. 3 reports the weighted population share for each category. 


\section{REFERENCES}

Ablorh-Odjidia, E. 2003. "From Pwalugu to Cancun: Toward Fair Agricultural Trade Policies.” Modern Ghana, September 29.

Ackah, C., and E. Kutsoati. 2008. Towards an Economic Transformation in Ghana: Strategic Learning from HighGrowth Nations. Working Paper 3. Accra, Ghana: African Centre for Economic Transformation.

Ackah, C., and D. Medvedev. 2010. "Internal Migration in Ghana: Determinants and Welfare Impacts." Paper presented at the Centre for the Studies of African Economies Annual Conference on Economic Development in Africa. March, Oxford, UK.

Agyeman-Duah, I., ed. 2008. An Economic History of Ghana: Reflections on a Half-Century of Challenges and Progress. Oxfordshire, UK: Ayebia Clark.

Akramov, K. T., and F. Asante. 2009. Decentralization and Local Services in Ghana: Do Geography and Ethnic Diversity Matter? Discussion Paper 872. Washington, DC: International Food Policy Research Institute.

Andrae, G. 1981. Industry in Ghana: Production Form and Spatial Structure. Uppsala, Sweden: Scandinavian Institute of African Studies.

Anríquez, G., and S. Daidone. 2008. Linkages between Farm and Non-Farm Sectors at the Household Level in Rural Ghana: A Consistent Stochastic Distance Function Approach. Working Paper 08-01. Agricultural and Development Economics Division of the Food and Agriculture Organization of the United Nations (FAO-ESA). Rome, Italy: UN FAO.

Aryeetey, E. 2005. Globalization, Employment and Poverty in Ghana. Working Paper. Institute of Statistical, Social and Economic Research.Legon, Ghana: University of Ghana.

Aryeetey, E., and W. Baah-Boateng. 2007. Growth, Investment, and Employment in Ghana. Working Paper 80. Geneva: International Labour Office. www.ilo.org/integration/resources/papers/lang--en/index.htm.

Aryeetey, E., and A. Fosu. 2002. Explaining African Economic Growth Performance: The Case of Ghana. Paper prepared for the African Economic Research Consortium, Kenya. www.isser.org/publications/older/Economic\%20Growth\%20in\%20Ghana\%202.pdf.

Aryeetey, E., and A. McKay. 2007. "Ghana: The Challenge of Translating Sustained Growth into Poverty Reduction." In Delivering on the Promise of Pro-Poor Growth: Insights and Lessons from Country Experiences, edited by L. Cord, 147-168. New York: Palgrave Macmillan.

Asmah, E. 2011. "Rural Livelihood Diversification and Agricultural Sector Reforms in Ghana." Paper presented at the 2011 Centre for the Studies of African Economies Annual Conference on Economic Development in Africa, Oxford, UK, March. www.csae.ox.ac.uk/conferences/2011-EDiA/papers/510-Asmah.pdf.

Barthel, F., M. Busse, and R. Osei. 2008. The Characteristics and Determinants of FDI in Ghana. Research Paper 2-15. Hamburg, Germany: Hamburg Institute of International Economics. www.hwwi.org/uploads/tx_wilpubdb/HWWI_Research_Paper_2-15.pdf.

Boateng, K. 1997. Institutional Determinants of Labour Market Performance in Ghana. Research Paper. Accra, Ghana: Centre for Economic Policy Analysis.

Bogetic, Y., M. Bussolo, X. Ye, D. Medvedev, Q. Wodon, and D. Boakye. 2007. “Ghana's Growth Story: How to Accelerate Growth and Achieve MDGs?” Background paper for Ghana Country Economic Memorandum. Washington, DC: World Bank.

Breisinger, C., X. Diao, S. Kolavalli, R. Al Hassan, and J. Thurlow. 2011. A New Era of Transformation in Ghana, Lessons from the Past and Scenarios for the Future. IFPRI Research Monograph. Washington, DC: International Food Policy Research Institute.

Breisinger, C., X. Diao, and J. Thurlow. 2011. Potential Impacts of a Green Revolution in Africa - The Case of Ghana, Journal of International Development 23: 82-102. 
Breisinger, C., X. Diao, S. Benin, J. Thurlow, and S. Kolavalli. 2010. Aiming for Middle-Income Country Status: What Are the Growth Options? Ghana Strategy Support Program-IFPRI Discussion Brief 1. Washington, DC: International Food Policy Research Institute. www.ifpri.org/sites/default/files/publications/gsspbrief01.pdf.

Breisinger, C., X. Diao, R. Schweickert and M. Wiebelt. 2010. "Managing Future Oil Revenues in Ghana: An Assessment of Alternative Allocation Options." African Development Review 22 (2): 303-315.

Breisinger, C., and X. Diao. 2008. Economic Transformation in Theory and Practice: What Are the Messages for Africa? Working Paper 10. Washington, DC: Regional Strategic Analysis and Knowledge Support System.

Breisinger, C., X. Diao, S. Kolavalli, and J. Thurlow. 2008. The Role of Cocoa in Ghana's Future Development. IFPRIGSSP Background Paper 11. Washington, DC: International Food Policy Research Institute.

Breisinger, C., X. Diao, J. Thurlow, B. Yu, and S. Kolavalli. 2007. Accelerated Growth and Structural Transformation: Assessing Ghana's Options to Reach Middle-Income Status. Background Paper No. GSSP 0007. Washington, DC: International Food Policy Research Institute. www.ifpri.org/sites/default/files/publications/gsspwp07.pdf.

Canagarajah, S., C. Newman, and R. Bhattamishra. 2001. Non-Farm Income, Gender, and Inequality: Evidence from Rural Ghana and Uganda. Food Policy 26: 405-420.

Carletto, G., K. Covarrubias, B. Davis, M. Krausova, and P. Winters. 2007. Rural Income-Generating Activities Study: Methodological Note on the Construction of Income Aggregate. Mimeo. Rome, Italy: Agricultural Sector in Economic Development Service, UN FAO. ftp://ftp.fao.org/docrep/fao/010/ai197e/ai197e00.pdf.

Collier, P., and J. W. Gunning. 1999. "Why Has Africa Grown Slowly?” The Journal of Economic Perspectives 13 (3): $3-22$.

Collier, P., and T. Venables. "Rethinking Trade Preferences: How Africa Can Diversify Its Exports." World Economy, forthcoming.

Coulombe, H., and Q. Wodon. 2007. Poverty, Livelihoods and Access to Basic Services in Ghana. Background paper for Ghana Country Economic Memorandum. Washington, DC: World Bank. http://siteresources.worldbank.org/INTGHANA/Resources/CEM_poverty.pdf.

Delgado, C., J. Hopkins, V. Kelly, P. Hazell, A. McKenna, P. Gruhn, B. Hojjati, et al. 1998. Agricultural Growth Linkages in Sub-Saharan Africa. Research Report 107. Washington, DC: International Food Policy Research Institute.

Dinye, R. D., and C. F. A. Nyaba. 2001. Trade Policy and Domestic Manufacturing in Ghana. Structural Adjustment Participatory Review International Network (SAPRIN)Research Report draft. Washington, DC: SAPRIN. www.saprin.org/ghana/research/gha_trade.pdf .

Ellis, F., and H. A. Freeman. 2004. "Rural Livelihoods and Poverty Reduction Strategies in Four African Countries." The Journal of Development Studies 40 (4): 1-30.

Encyclopedia of the Nations, nd. "Ghana: Manufacturing and Tourism." www.country-data.com/cgi-bin/query/r5282.html.

Eichengreen, B. and P. Gupta. 2011. The Service Sector as India's Road to Economic Growth. National Bureau of Economic Research Working Paper Series Vol. w16757. Cambridge, MA: NBER.

FAO, 2008. Soaring Food Prices: Facts, Perspectives, Impacts and Actions Required. Paper prepared for the high-level conference on World Food Security: The Challenges of Climate Change and Bio-Energy. Rome, Italy, June 3-5.

GSS (Ghana Statistical Service). 1995. Ghana Living Standards Survey, Report of the Third Round (GLSS 3). Accra, Ghana.

2000. Ghana Living Standards Survey, Report of the Fourth Round (GLSS 4). Accra, Ghana

. 2002. 2000 Population and Housing Census, Summary Report of Final Results. Accra, Ghana.

.2007. Ghana Living Standards Survey, Report of the Fifth Round (GLSS5). Accra, Ghana.

. 2011a. Ghana Gross Domestic Product Data (GDP). Accra, Ghana. Last accessed December 12, 2011.

www.statsghana.gov.gh/gdp.html. 
.2011b. Mimeo of country statistics. Accra, Ghana.

Harberger, A.C. 2010. Observing the Ethiopian Economy. A report prepared for USAID. Mimeo. www.econ.ucla.edu/harberger/ethiopia2010.pdf .

Hausmann, R., J. Hwang, and D. Rodrik. 2006. "What You Export Matters”. Journal of Economic Growth 12(1): 1-25. .

Headey, D., D. Bezemer, and P. B. Hazell. 2010. “Agricultural Employment Trends in Asia and Africa: Too Fast or Too Slow?" The World Bank Research Observer 25(1): 57-89.

IFPRI (International Food Policy Research Institute). 2007. Ghana: Social Accounting Matrix (SAM), 2005, ed. C. Breisinger, J. Thurlow and M. Duncan; IFPRI data set and documentation. http://www.ifpri.org/dataset/ghana.

ISSER (Institute for Statistical Social and Economic Research). Various years. The State of the Economy Reports. Accra, Ghana.

Jebuni, C., S. Asuming-Brempong, and K. Y. Fosu. 1990. The Impact of Economic Recovery Programmes on Agriculture in Ghana. Report. Accra, Ghana: United States Agency for International Development.

Jedwab, R. 2011. African Cities and the Structural Transformation: Evidence from Ghana and Ivory Coast. Presented at the Centre for the Studies of African Economies Annual Conference, March 2011. www.csae.ox.ac.uk/conferences/2011-EDiA/papers/149-Jedwab.pdf.

Kingdon, G., J. Sandefur, and F. Teal. 2006. "Labour Market Flexibility, Wages and Incomes in Sub-Saharan Africa in the 1990s." African Development Review 18 (3): 392-427.

Kolavalli, S. and M. Vigneri. 2011. Cocoa in Ghana: Shaping the Success of an Economy. In Yes, Africa Can: Success Stories from a Dynamic Continent, edited by P. Chuhan-Pole and M. Angwafo, 201-217. Washington, DC: World Bank.

Larbi, W. O. 2006. Land Administration Reform in a Plural Environment: The Case of Ghana. Paper presented at the Fifth International Federation of Surveyors(FIG) Regional Conference, Accra, Ghana, March 8-11.

Lay, J., and D. Schuler. 2007. "Income Diversification and Poverty in a Growing Agricultural Economy: The Case of Ghana.” Mimeo. http://econstor.eu/bitstream/10419/39907/1/AEL_2008_39_schueler.pdf.

Lejarraga, I. 2010. Roaring Tiger or Purring Pussycat: A Growth Diagnostic Study of Ghana. Paper presented at the annual meeting of the American Economic Association, Atlanta, January 4.

Marr, A. 1997. Foreign Direct Investment Flows to Low-Income Countries: A Review of the Evidence. Briefing Paper 3, Overseas Development Institute, London. www.odi.org.uk/resources/download/1962.pdf.

Mellor, J. 1976. The New Economics of Growth. Ithaca, NY, US: Cornell University Press.

Melo, P. C., D. J. Graham, and R. B. Noland. 2009. "A Meta-Analysis of Estimates of Urban Agglomeration Economies.” Regional Science and Urban Economics 39: 332-342.

Nankani, G. nd. "The Challenges of Agriculture in Ghana: What Is to Be Done?” Mimeo. www.gnankani.com/pdf/The_Challenge_of_Agriculture_in_Ghana.pdf

2010. Medium Term Development Policy Framework: Ghana Shared Growth and Development Agenda (GSGDA): 2010-2013. www.ndpc.gov.gh/GPRS/Final\%20Draft\%20Policy\%20Framework\%20092010.pdf.

Nsowah-Nuamah, N., F. Teal, and M. Awoonor-Williams. 2010. Jobs, Skills and Incomes in Ghana: How Was Poverty Halved? WPS/2010-01. Oxford, UK: Centre for the Study of African Economies.

Oak Ridge National Laboratory. 2002. LandScan ${ }^{\mathrm{TM}}$ Global. Last accessed December 12, 2011. http://www.ornl.gov/sci/landscan/index.shtml.

Quiñones, E. J., and X. Diao. 2011. Assessing Crop Production and Input Use Patterns in Ghana: What Can We Learn from the Ghana Living Standards Survey (GLSS5)? GSSP Working Paper No. 0024. Washington, DC: International Food Policy Research Institute.

Ramatu, A.-H., and I. Egyir. 2002. "The Potential for Farm/Non-Farm Linkages in the Cassava Subsector in Ghana." In Promoting Farm/Non-Farm Linkages for Rural Development: Case Studies from Africa and Latin America, 
edited by B. Davis, T. Reardon, K.G. Stamoulis, and P. Winters, 171-198. Rome: Food and Agriculture Organization of the United Nations. ftp://ftp.fao.org/docrep/fao/005/y4383E/y4383E00.pdf.

Robinson, E. J. Z., and S. Kolavalli. 2010. The Case of Tomato in Ghana, Processing. GSSP Working Paper 21. Washington, DC: International Food Policy Research Institute.

Rodrik, D. 2006. "Industrial Development: Stylized Facts and Policies." Unpublished memo. www.ksg.harvard.edu/rodrik.

. 2008. The Real Exchange Rate and Economic Growth. Brookings Papers on EconomicActivity Fall 2008 Conference Draft, edited by D.W. Elmendorf, N.G. Mankiw, and L.H. Summers. Washington, DC: Brookings Institution. www.brookings.edu/ /media/Files/Programs/ES/BPEA/2008_fall_bpea_papers/2008_fall_bpea_rodrik.pdf.

Röller, L.-H., and L. Waverman. 2001. "Telecommunications Infrastructure and Economic Development: A Simultaneous Approach.” The American Economic Review 91 (4): 909-923.

Sachs, J. D., and A. M. Warner. 1995. "Economic Reform and the Process of Global Integration.” Brookings Papers on Economic Activity 1: 1-118.

. 2001. "The Curse of Natural Resources.” European Economic Review 45 (4-6): 827-838.

Sandefur, J. 2010. On the Evolution of the Firm Size Distribution in an African Economy. Center for the Study of African Economies Working Paper Series 2010/05. Oxford, UK: Department of Economics, Oxford University.

Steedman, C. 2003. "Agriculture in Ghana: Some Issues.” Mimeo. World Bank.

Steel, W. F. 1972. "Import Substitution and Excess Capacity in Ghana." Oxford Economic Papers 24 (2): 212-240.

Stryker, J., and E. Dumenu. 1986. "A Comparative Study of the Political Economy of Agricultural Pricing Policies: The Case of Ghana.” Unpublished paper. Washington, DC: World Bank.

Teal, F. 1999. Why Can Mauritius Export Manufactures and Ghana Not? WPS/99-10. Oxford: Centre for the Study of African Economies, University of Oxford. http://www.csae.ox.ac.uk/workingpapers/pdfs/2010-05text.pdf

Uchida, H., and A. Nelson. 2010. Agglomeration Index: Towards a New Measure of Urban Concentration. Working Paper No. 2010/29. United Nations University-World Institute for Development Economics Research (UNUWIDER)Working Paper No. 2010/29. Helsinski, Finland:. UNU-WIDER. www.wider.unu.edu/stc/repec/pdfs/wp2010/wp2010-29.pdf

United Nations. 2010. Commodity Trade Statistics Database (Comtrade). http://comtrade.un.org/db/.

World Bank, nd. Ghanaian Labor Market, Key Trends and Major Policy Issues. http://info.worldbank.org/etools/docs/library/211239/Ghana_KeyTrends-and_\%20Policy_Issues.pdf.

1994. Adjustment in Africa: Reforms, Results, and the Road Ahead. Oxford University Press: New York 2007. Ghana: Meeting the Challenge of Accelerated and Shared Growth. Country Economic Memorandum, Volumes 1, 2, and 3. Washington, DC.

. 2009a. Ghana: Economy-Wide Impact of Oil Discovery in Ghana. Report No. 47321-GH. Washington, DC. .2009b. Ghana: Job Creation and Skills Development. Report No. 40328-GH. Washington, DC.

.2009c. Reshaping Economic Geography. World Development Report. 2009. Washington, DC.

. 2009d. World Development Indicators. 2009. Washington, DC. http://data.worldbank.org/indicator. 2010. Republic of Ghana: Tackling Poverty in Northern Ghana. Report No. 53991-GH. Washington, DC.

Yumkella, K., T. Roepstorff, J. Vinanchiarachi, and T. Hawkins. 1999. Globalization and Structural Transformation in Sub-Saharan Africa. Paper presented at the United Nations Industrial Development Organization (UNIDO) Workshop on Agricultural Transformation in Africa, Nairobi, Kenya, June 1999.

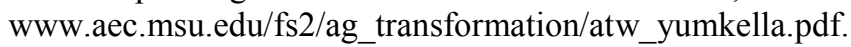

Yusof, Z. A. 2010. Economic Growth in Malaysia: Some Possible Lessons for Ghana. Discussion Paper 10/0827. London: International Growth Centre. http://eprints.lse.ac.uk/36388/. 



\section{RECENT IFPRI DISCUSSION PAPERS}

\section{For earlier discussion papers, please go to www.ifpri.org/pubs/pubs.htm\#dp. All discussion papers can be downloaded free of charge.}

1160. Globalization, structural change, and productivity growth. Margaret McMillan and Dani Rodrik, 2012.

1159. A review of input and output policies for cereals production in India. Ganga Shreedhar, Neelmani Gupta, Hemant Pullabhotla, A. Ganesh-Kumar, and Ashok Gulati, 2012.

1158. Demand and supply of cereals in India: 2010-2025. A. Ganesh-Kumar, Rajesh Mehta, Hemant Pullabhotla, Sanjay K. Prasad, Kavery Ganguly, and Ashok Gulati, 2012.

1157. Close eye or closed eye: The Case of export misinvoicing in Bangladesh. Pranav Kumar Gupta, Devesh Roy, and Kaikaus Ahmad, 2012.

1156. The sophistication and diversification of the African Agricultural sector: A Product Space Approach. John Ulimwengu and Thaddée Badibanga, 2012.

1155. Why women are progressive in education?: Gender disparities in human capital, labor markets, and family arrangement in the Philippines. Futoshi Yamauchi and Marites Tiongco, 2012.

1154. Resource-rich yet malnourished: Analysis of the demand for food nutrients in the Democratic Republic of Congo. John Ulimwengu, Cleo Roberts, and Josee Randriamamonjy, 2012.

1153. Putting gender on the map: Methods for mapping gendered farm management systems in Sub-Saharan Africa. Ruth Meinzen-Dick, Barbara van Koppen, Julia Behrman, Zhenya Karelina, Vincent Akamandisa, Lesley Hope, and Ben Wielgosz, 2012.

1152. Household preferences and governance of water services: A Hedonic analysis from rural Guatemala. William F. Vásquez, 2011.

1151. Peer effects, risk pooling, and status seeking: What explains gift spending escalation in rural China? Xi Chen, Ravi Kanbur, and Xiaobo Zhang, 2011.

1150. Agricultural productivity and policies in Sub-Saharan Africa. Bingxin Yu and Alejandro Nin-Pratt, 2011.

1149. Common-pool resources, livelihoods, and resilience: Critical challenges for governance in Cambodia. Blake D. Ratner, 2011.

1148. The impact of global climate change on the Indonesian economy. Rina Oktaviani, Syarifah Amaliah, Claudia Ringler, Mark W. Rosegrant, and Timothy B. Sulser, 2011.

1147. Evaluating the Mexico City Policy: How US foreign policy affects fertility outcomes and child health in Ghana. Kelly M. Jones, 2011.

1146. Income shocks and HIV in Sub-Saharan Africa. Marshall Burke, Erick Gong, and Kelly Jones, 2011.

1145. Emerging policies and partnerships under CAADP: Implications for long-term growth, food security, and poverty reduction. Ousmane Badiane, Sunday Odjo, and John Ulimwengu, 2011.

1144. Girls take over: Long-term impacts of an early stage education intervention in the Philippines. Futoshi Yamauchi and Yanyan Liu, 2011.

1143. The broken broker system?: Transacting on agricultural wholesale markets in India (Uttarakhand). Bart Minten, Anneleen Vandeplas, and Johan F.M. Swinnen, 2011.

1142. Responding to land degradation in the highlands of Tigray, Northern Ethiopia. Tyhra Carolyn Kumasi and Kwadwo Asenso-Okyere, 2011.

1141. The quiet revolution in agrifood value chains in Asia: The case of increasing quality in rice markets in Bangladesh. Bart Minten, K.A.S. Murshid, and Thomas Reardon, 2011.

1140. Sanitary and phytosanitary standards as bridge to cross. Abdul Munasib and Devesh Roy, 2011.

1139. Climate change and floods in Yemen: Impacts on food security and options for adaptation. Manfred Wiebelt, Clemens Breisinger, Olivier Ecker, Perrihan Al-Riffai, Richard Robertson, and Rainer Thiele, 2011. 


\section{INTERNATIONAL FOOD POLICY}

RESEARCH INSTITUTE

www.ifpri.org

IFPRI HEADQUARTERS

2033 K Street, NW

Washington, DC 20006-1002 USA

Tel.: +1-202-862-5600

Fax: +1-202-467-4439

Email: ifpri@cgiar.org 